\title{
MASS SPORTS PRACTICE AND THE NATIONAL STRATEGIC DOCUMENTS
}

\section{PRACTICA DEL DEPORTE DE MASAS Y DOCUMENTOS NACIONALES ESTRATÉGICOS}

\author{
Dušan Mitić \\ Faculty of Sport and Physical Education, University of Belgrade, Serbia
}

\begin{abstract}
The modern society's agendas are filled with the activities which are designed to improve the quality of life of an individual, family, community as well as the entire society through physical activity and exercise. Many documents of professional, scientific, and even political international bodies and organizations, as well as the documents adopted at the level of individual states, deal with public health and activities aimed at promoting healthy lifestyles and providing all citizens with the opportunities to engage in Law on Sports which have become one of the priorities included in the development agendas in this millennium. Both national and international documents and initiatives include recreational sports, in addition to citizens' individual activity, at the core of professional effort and political action, sharing a common goal of achieving health benefits significant to both individuals and the entire society through mass physical exercise. The subject of this paper referred to the documents and practices of recreational sports assessment and organization since 2006 - full state independence of the Republic of Serbia. The aim of the paper was to examine the things done so far as well as the position of citizens physical activity within the future social development agendas.
\end{abstract}

Key words: RECREATIONAL SPORTS / PUBLIC HEALTH / SPORTS DEVELOPMENT STRATEGY / SERBIA

\section{INTRODUCTION}

Physical activity is the basic factor that contributes to the health of the individual and the population as stated by Dr Andrew F. Maneley in the Report for "Surgeon General of the US (1996)" who pointed out: "Although the science of physical activity and exercise is a complex area - field which is still developing, today there are many strong, scientifically verified facts

\begin{abstract}
EXTRACTO
Las agendas de la sociedad contemporánea están llenas de actividades por las cuales, a través de la actividad física y los ejercicios, se trabaja en mejorar la calidad de vida del individuo, la familia, la comunidad y la sociedad en total. En muchos documentos de los cuerpos y organizaciones profesionales, científicas o políticas, así como también en los documentos aprobados en nivel de Estados individuales, la salud pública y las actividades con el fin de promover estilos de vida saludables y dar posibilidad a todos los ciudadanos de practicar en las actividades deportivas, se convirtieron en una de las prioridades de la agenda de desarrollo en este milenio. Tanto en los documentos e iniciativas nacionales, como también en los internacionales, la recreación deportiva, con la actividad individual de los ciudadanos, están en la esencia del esfuerzo profesional y la actividad política y con el objetivo común que es llegar, a través de ejercicio físico en masa, al beneficio de salud de importancia para el individuo y la sociedad en total. El objeto del presente trabajo se refiere a los documentos y la práctica de valorar y organizar el deporte recreativo a partir del año 2006 - plena independencia estatal de la República de Serbia. El objetivo del trabajo es observar lo hecho y posicionar la actividad física de los ciudadanos en las próximas agendas del desarrollo social.
\end{abstract}

Palabras claves: RECREACIÓN DEPORTIVA / SALUD PUBLICA / ESTRATEGIA DE DESARROLLO DEL DEPORTE / SERBIA

and evidence that clearly indicate that regular physical activity and exercise affect human health very favourably. The modern society's agendas are filled with activities that, through physical activity and exercise, are aimed at improving the quality of life through the affirmation of physical activity at all levels, from an individual, family, to organization of the community 
and the state. Since physical activity is directly related to preventing illness and premature death, as well as maintaining a high quality of life, it has to be paid as much attention as to other health issues of general social importance. In this way, physical activity and physical exercise are placed within the framework of processes within which there are healthy environment, nutrition or the use of safety belts and the fight against smoking. "The potential value of physical activity and physical exercise, as a means of prevention and measures in the preservation of health, is enhanced by its accessibility, security and the ability to be accepted by a large number of people."

Simultaneously with the conclusions and recommendations of the level (professional and scientific associations and organizations), the first decade of the $21^{\text {st }}$ century can be described with political initiatives in the area of affirmation of physical activity and physical exercise itself. Thus, the Lisbon Treaty (1998), the White Paper on Sport (2004), the World Health Organization's Recommendation on Nutrition and Physical Activity (2007), as well as many other documents, resolutions, recommendations ... were political grounds for the EU decision (December 2010) that by 2020, the new 100,000,000 Europeans will start doing regular physical activity. The regular physical activity is the basis for preservation and improvement of health, and the "Sport for All" movement is recognized as a place within which the realization of these goals can be achieved, as written among other things in the above documents, but also in the statements of the officials. In the listed documents, as well as in documents adopted at the level of individual countries (EU members and those which are not) public health and activities aimed at promoting healthy lifestyles and providing opportunities for all citizens to engage in sporting activities is one of the priorities recognized by the United Nations and its agencies and listed it the world's programs in the new millennium.

"Sport for All", as a civil society movement, offers the opportunity to practice physical exercise and the sport of all citizens. It is realized as a recommendation that Law on Sports should be carried out throughout the year, at least twice a week. "Sport for All" is a means to create a healthy, ethical nation with working capacity (by reducing the cost of treatment, prolonging the work life, healthier and more satisfied employees and citizens...).
Both in national and international documents and initiatives, recreational sports, along with activities of citizens through training and competition of sports branches (the system of sports in the narrow sense), educational system (all levels of the education system), physical training in institutions and corporations....are in the core of professional effort and political action with the common goal, which is to achieve benefits of importance to the individual and society as a whole by mass physical exercising.

The European space is further united through sport. The perspective of uniting the whole continent through sport is passed by the resolutions of ministers responsible for sport, organized by the Council of Europe. At meeting in 2011, the ministers of 49 European countries recognized the health and social value of physical exercise (physical exercise for the purpose of health, social inclusion, human rights, democratic development, regional politics, culture, education, new jobs, volunteer organization...) and have opted for physical exercise (sport) as a means of creating a European dimension. The starting point for this document was the "White Paper" (2007), by which the EU recognized the importance of physical activity for preserving health. This document recommends building strong links with the health, education and sports systems. The next important document of the political initiatives adopted at the meeting of the ministers of the Council of Europe (CE) in charge of sports (2008), which adopted the "European manual for physical activity". This document of the CE united efforts to reach a more quality European perspective for the lives of all citizens by strengthening links between health, education, transport and urban development. By adopting the Lisbon Declaration (2009), the European Union has emphasized its explicit competences in the field of sports, and for the first time "strongly" included sport in the European Charter. So, the EU and the CE have politically promoted the importance and role of physical exercise (sport) in the function of developing the continent! The question is asked what and how the profession and politics in Serbia have done in the indicated period, from the year of its full state independence (2006). The subject of this paper deals with the documents and practice of evaluating and organizing recreational sports since the year of full state independence of the Republic of Serbia. The aim of the paper is to examine the positioning of physical activity of citizens in the function of health and the current organization of mass sports 
in Serbia in relation to Pan-European ideas and documents.

\section{THE MEANING OF MASS SPORT - UNITY OF RECREATION AND SPORT}

The search for defining mass sports is essentially a search for the meaning of physical activity and the exercise of all citizens. The first step on this path is to define the meaning of the term "RECREATION". Explaining the thesis of Blagajac that "Recreational sports represents a culturally, physically active and healthy way of life", Matić (1991, p. 286) says that this is an action fulfilled with a certain activity ... i.e. that recreation is a special contribution to managing one's own life". Matić (1992) talked about recreation as of creation of a being... that is, that recreation represents "AN EFFORT TO ACHIEVE ONESELF".

From the perspective of a psychologist who has been persisting on a regular mid-day running "for recreational purposes", Branko Pokrajac points to the fact that psychologists seldom deal with the wellbeing and positive aspects and effects of recreation in healthy people, and that the concept of happiness is difficult to find in analyses. He promotes the idea that "recreational sport" (or recreation by physical exercising) should be a planned activity by which one is striving for improvement or maintenance of the physical and psychological well-being of man; "recreation is the restoration of physical and mental powers." The state in which the participant in recreation achieves is "a deeper experience of happiness, which does not occur in any kind of chase, but only if the person is related to activity, if he perceives it as relevant to some qualities or abilities closer to the centre of his I-concept." (Pokrajac, 1992).

A recognized scientist and one of the first professors of Belgrade's DIF, Dr Smodlaka says: "Recreation is a movement of most diverse activities with the aim of raising working ability, quality of life and general emotional state, joy of life" (Smodlaka, a letter as of September $11^{\text {th }} 1995$ )

"Emotional well-being" - "a healthy lifestyle", "an effort to achieve oneself" in conditions of the "leisure time work company" (to which we obviously strive) is a starting point for our further consideration of people who have their own recreational program.

Respecting the fact that the point of support of recreation is its attitude towards strengthening - refresh- ment - preparation for new work and better quality of life, it is noticed that commitment and investment of an individual and the society in recreational projects are both in terms of volume and intensity, and in separate finances..., they go beyond those that were registered in the last century, at the initial stage of its modern comprehension. Therefore, the real prerequisite for recreation is the willingness to invest in a program for the development of one's own personality!

Recreational sport, in accordance with EU standards and recommendations, is a practice done regularly (minimum once a week), according to quality programs, under the guidance of qualified persons, at adequate sports facilities and with appropriate medical control.

Sport, on the other hand, must be viewed using a dual approach, (both) as a means of physical activity and physical training of a man, (and) as a sport in the narrow sense, that is, training and competition. It will be analysed in this paper solely as a means that enriches the nature of a man to be physically active. As a physical exercise, sport contributes to personal and social development; it is a means of meeting the human need for physical exercise for personal physical and mental well-being. Modern studies promote sport, and thus physical exercise of man through the benefits in the area of intellectual, social, affective, psychological, biological and motor significance... Therefore, sport is especially valuable for a modern man and a fast-changing world, which, on the one hand, is characterized by an increase of leisure time, and on the other hand by urbanization and constant technological development that seeks to separate people from his social environment and move him to the virtual world of social networks and events.

Regular physical activity, sports and recreation can play an important and active, constructive role in strengthening physical, intellectual and moral health of the population. It is one of the key elements in achieving human values and in actions that are being implemented against various prejudices, discrimination and the idea of violence. Physical activity and sport contribute to social cohesion, overcoming prejudices, increasing the positive impact on public opinion and spreading ethical and general principles that are transmitted through it. In proportion to the stated importance of physical activity and sports, their affirmation and development must be supported and encouraged at all levels of society from the family and local community to the national state. 


\section{RECREATION IN LEGAL AND STRATEGIC DOCUMENTS OF SIGNIFICANCE FOR THE DEVELOPMENT OF SOCIETY AND PROFESSION}

As current practice in Serbia shows, the state also takes care of the organization of society through physical activity and physical exercise. The whole century has passed until this relationship, and it can be described with two periods, the first of which belongs to Serbia as part of a state union (KSHS, KY, FNRS, SFRY, FRY, SCG), or a different period since June 2006, the year of the state independence of the Republic of Serbia. For a comprehensive analysis according to the subject of this paper, the period after the Second World War, from the fifties of the last century to 2006, is interesting, marked by state concern about physical education, sports and mass sports. Due to the need to prove the success of the functioning of the socialism model during the FNRY-SFRY period, it was invested in the development of sport that for years justified this investment. In addition to the care of elite sports, the state of these days took care of other registered athletes and mass forms of physical culture. Social turmoil and transition, which began in the mid-1980s, significantly influenced the overall attitude of the state towards recreation of citizens.

The first Act on Sport of the Republic of Serbia was passed in 1996. This law, in a terminological and substantive sense, dealt only with sports, while the recreation of citizens became a practical concern for the individual, without serious support of the society. The sports system, especially its international level, which was under sanctions (1992-1996), and which lost its visibility but also the importance of results that it had in previous periods, began to be carried out through two processes: the first one followed the decline of interest, cancelling certain sports branches, institutions, publications and the like, and others, which described the renunciation of the sport's autonomy, which could be described by adapting and functioning of sports in accordance with the interests of the state. The above, combined with a prolonged economic crisis and sanctions, led to some new value of orientation of the sport movement, which could be described by cancelling amateurism and voluntarism in sports in the broadest sense.
The formation of the Ministry of Youth and Sports (2007) led to the elaboration and adoption of the first and then the second government strategy for the development of sports in Serbia. The first strategy that covered the period 2009-2013 and the Law on Sports of 2009 created an environment with predictable conditions for the development of sports in the widest sense. The focus of the first strategy was on the sport of children and youth, the development of elite sport and the revitalization and construction of sports infrastructure. The Law on Sports and the package of adopted by-laws regulated the development and financing of sports on the basis of two criteria, the first sporting result in a given sports branch, while the other refers to the program orientation of the parent sports federation. The Strategy for the Development of Sport in the Republic of Serbia for the period 2014-2018 sets the priority of increasing the coverage of citizens who have regular physical activity and the development of school sports and sports infrastructure. In this way, the Republic of Serbia is approaching the European value system, which states that the state of a nation in terms of sports is reflected in how much the country takes care of every citizen and the creation of conditions for everyone to practice sports.

According to the Law on Sports of the Republic of Serbia (2016), encouraging and creating conditions for improving recreational sports, that is, citizens dealing with sports is a priority area of the needs and interests of the society. The law regulates that everyone has the right to be engaged in sports, and that sport must be humane, free and voluntary, healthy and safe, accessible to all citizens under equal conditions regardless of age, level of physical ability, degree of disability, gender and other personal property. Any discrimination in sport is forbidden! Public authorities at all levels are responsible, either directly or by training others, to improve access to sport and sports facilities of all citizens, regardless of their social background, economic status and income, age, gender or ethnicity. Sport must not be the exclusive right of protected categories, but available to all citizens! These allegations from the Law on Sports are based on the Constitution of the Republic of Serbia (2006), which lists sports, physical culture and physical exercise of citizens in several places, thus introducing them into the constitutional category. It must be pointed out that in 2006, it was very important that the profession of sports in the broadest sense recognized, designed and lobbied for the purpose of defining the physical 
activity of citizens in the Constitution of the Republic of Serbia as an independent state.

Pursuant to the constitutional and legal guidelines, the public authorities of all levels of the organization of the state are obliged to contribute to the realization of goals that are clearly defined by the Law on Sports, both from 2011 and the latest from 2016, by developing strategies and programs for sport development and financing sports programs. Both laws stipulate the promotion and creation of conditions for the improvement of recreational sports, i.e. the involvement of citizens in sports, especially children, youth, women and persons with disabilities, but also the construction, maintenance and equipping of sports facilities, education, information and counselling of citizens, athletes and other participants in a system of sports on issues essential for proper engagement with Law on Sports activities.

The Law on Sports of 2016, in Article 3, paragraph 3 , defines that recreational sports (recreational sport, sports for all, mass sports) is a field of sport that includes voluntary physical exercise, i.e. Law on Sports for rest, refreshment, entertainment, advancement health or improvement of their own results and in order to satisfy the needs for movement, play and socializing, in all segments of the population.

The next important document for affirmation of legal solutions in the Republic of Serbia refers to the Rulebook on sports branches from 2016. With this document, signed by the Minister of Sports, sports and sports disciplines in the Republic of Serbia have been defined. Among them is recreational sports (sport for all, recreational sports, mass sports): in both competitions (women and men of all ages). The goals of recreational sports are realized through the planning and implementation of educational activities with children, youth and adults.

The latest and previous law facilitates the ability to recognize and register new sports, form clubs and associations. Legislative changes have allowed the number of registered sports and sports federations to be tripled for the last decade. What is important to point out, as Serbian specificity, in this process is the acceptance of the tendency of increased participation of women in sports, and so has increased the number of sports and disciplines in which women compete. Women became more often represented in the Olympic delegations, and $50 \%$ of medals from the last Olympic Games in Rio (2016) were won by women.

\section{REGULAR PHYSICAL ACTIVITY OF CITIZENS - NATIONAL CHALLENGE AND A STRATEGIC PRIORITY}

Since its founding, the World Health Organization (WHO) has been trying to pinpoint the positive effects of regular physical activity in all citizens' structures through "open letters" addressed to all governments of the world. It points out that insufficient physical activity, evident in everyday life and work, especially its absence, endangers pre-school children, adolescents, people with stress situations, women, older persons and persons suffering from chronic non-communicable diseases (obesity, hypertension, diabetes mellitus, osteoporosis ...). Insufficient physical activity or hypokinesia, as is commonly referred to, is designated as an independent risk factor for the lives of the listed categories of citizens (Vuori, 1996).

The personal regime of life and lifestyle has $50 \%$ of the importance for the health status of the hard, says Hrcka, (Hrcka, 1990). A healthy lifestyle, which implies a regime of life, work, a healthy environment, a diet, resting and a whole range of free-time activities in which it can undergo self-certification, is obviously not just an individual's problem, because the endangerment of the individual disrupts the stability of the family and through it the wider social communities.

The Eurobarometer survey data from 2002 indicate that two thirds of the adult population in the European Union (EU) is physically insufficiently active in achieving optimal health benefits (European Opinion Research Group 2003). Also, due to the advancement of technology and the described social changes, physical inactivity is becoming an increasing problem for children and youth.

According to the data of the research of the Institute of Public Health of Serbia "Dr Milan Jovanovic Batut" in the Republic of Serbia (Table 1), almost every fifth adult citizen (18.6\%) is obese, every third inhabitant consumes cigarettes (33.6\%), about $40 \%$ daily or occasionally consumes alcohol, and nearly half of the population has hypertension (46.5\%). 
Table 1 Frequency of disease or a condition of population aged 20 or more, Serbia, 2000, 2006 and 2013.

\begin{tabular}{lccc}
\hline Diseases/conditions & $\mathbf{2 0 0 0}$ & $\mathbf{2 0 0 6}$ & $\mathbf{2 0 1 3}$ \\
\hline Hypertension & $\mathbf{9}$ & $\mathbf{\%}$ & $\mathbf{\%}$ \\
$\begin{array}{l}\text { Deformities of the lower spine or other chronic problem with } \\
\text { back (back pain) }\end{array}$ & 19,7 & 23,1 & $\mathbf{3 3 , 2}$ \\
Neck deformity or another chronic neck problem & 4,6 & - & 20,3 \\
Cholesterol & 5,7 & 8,0 & $\mathbf{1 3 , 0}$ \\
Arthrosis - degenerative disease of joints (without arthritis) & 5,0 & - & $\mathbf{1 1 , 0}$ \\
Coronary disease or angina pectoris & - & - & $\mathbf{9 , 9}$ \\
Allergy (without asthma allergy) & - & 5,3 & 8,9 \\
Diabetes & - & 5,3 & $\mathbf{8 , 1}$ \\
Depression (or chronic anxiety) & 4,6 & 6,0 & $\mathbf{6 , 7}$ \\
\hline
\end{tabular}

The research of this Institute and the Ministry of Health in 2013 showed that $8.8 \%$ of occupants had a physical activity, sports or recreational sport at least three times a week. $4.8 \%$ of the population of the Republic of Serbia had physical activity, aimed at strengthening muscles, at least three times a week, in 2013.

Based on longitudinal population weight monitoring studies, in $2013,40.4 \%$ of the optimally nourished population was registered in the Republic of Serbia. More than half of the population is over-nourished (56.3\%), of which $35.1 \%$ are classified as moderately obese, i.e. $21.2 \%$ in the group of obese. In the Republic of Serbia, between two surveys, 2006 and 2013, there is a significant increase in the percentage of obese population (from $17.3 \%$ to $21.2 \%$ ). The same research also brings the trend of increasing chronic non-communicable diseases (Table 1). There is an increase in hypertension from $23.1 \%$ to $33.2 \%$. Increased fats in blood (total cholesterol) increased from $8 \%$ in 2006 to $13 \%$ of the population in 2013. There is an increase in the number of individuals suffering from some type of diabetes (from $5.3 \%$ to $8.1 \%$ ).

In the same period, from 2006 to 2013, there was an increase in childhood obesity ( $2.6 \%$ to $4.9 \%)$ (Chart 1)

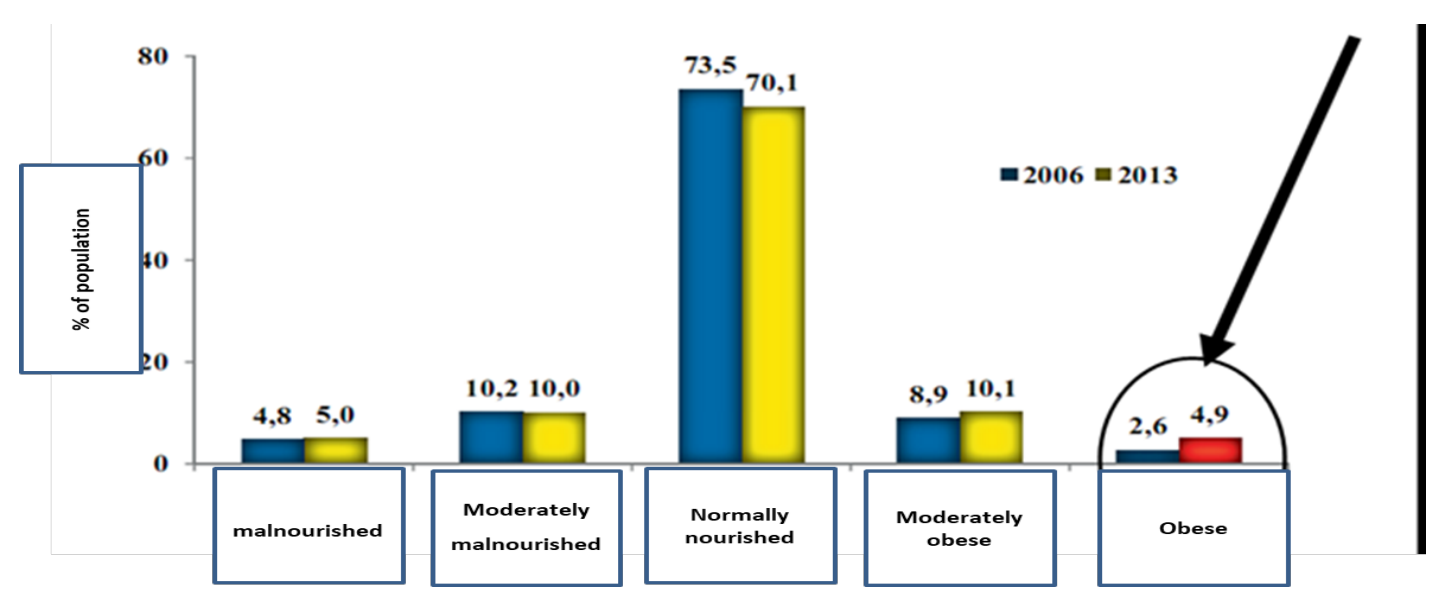

Chart 1. Nourishment of children and youth aged 7-14, Serbia 2006 (blue) and 2013 (yellow) 


\section{By increasing the coverage of citizens to the realization of the strategic goals of mass sport}

The goals of the Sports Strategy are that the field of sports for all, recreational, mass sports and recreational sports includes the entire population. In relation to this goal, for now there is no systematic monitoring of the content and activities, in which citizens participate, as most of them, as well as throughout Europe, organize and participate in some form of physical exercise - activities.

One of the sources in the evaluation of citizens' coverage of physical activity may be data that is periodically issued by the Ministry of Youth and Sports. Thus, if it is assumed that an increase in the number of organizations is accompanied by an increase in the coverage of the population, according to a criterion, such as the name of the organization itself, it is concluded that the most represented sports organizations in the area of football, basketball, karate, volleyball and recreational sports (counting together recreational sport and sports for everyone). According to these data, $16.92 \%$ of all organizations or 3047 of them belong to football, basketball has 811 organizations (4.50\%); karate - 750 (4.17\%); volleyball - 643 $(3.57 \%)$. Of the sports organizations that form the body of recreational sports organizations, there are 638 organizations that have fitness $(3.54 \%)$ in the title, while there are 606 registered organizations in sport fishing. under the name recreational sport there are 567 organizations; body building - 337; aerobics - 223; dance (sports, modern) - 249; mountaineering - 241; aerobics - 223; sport for all - 201; aikido - 213; yoga - 169; bowling - 72; orienteering - 67; workers' sport - 61; traditional sports - 41; multi sports - 241 . Citizens' coverage is expanded through sports of persons with disabilities with 93 organizations, sports for persons with disabilities, deaf and with hearing problem - 24; Sokolski sport - 19 organizations; village sports - 18; sport of persons with disabilities, blind and weak-sighted people - 17; sport of persons with disabilities, Special Olympics - 13; while 10 organizations are engaged in sports in the diaspora.

Continuous monitoring has also taken place in Serbia (Graph 2). When comparing the results of the questionnaire on the frequency of recreation in the workforce of citizens in the past ten years, some fairly stable values are noticed, while unfortunately there is an increase in the number of people who never exercise, while at the same time the number of those who practice most regularly is decreasing (3-4 times a week) (Chart 2).

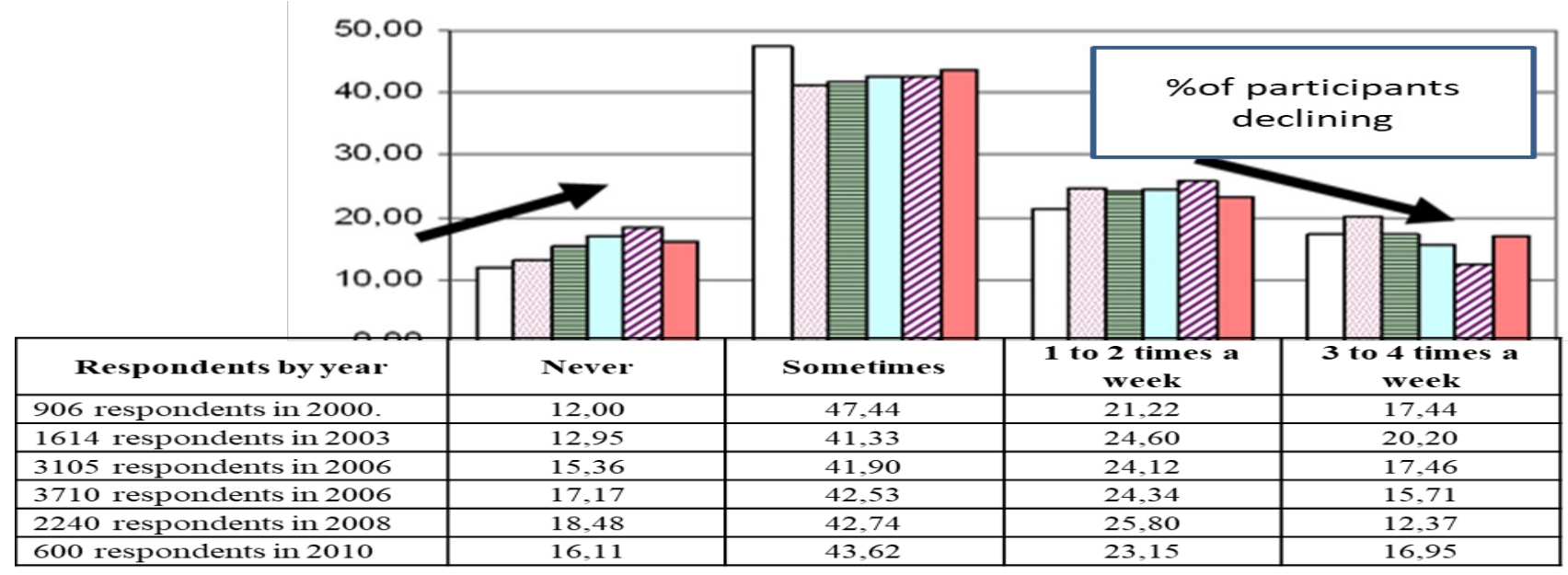

Chart 2. Recreation of employees in the period from 2000 to 2010 


\section{THE VISION OF RECREATIONAL SPORTS OF SERBIA - FROM THE INITIATIVE OF A PERSON TO STRATEGIC AND PROGRAM ACTIVITIES OF LOCAL SELF- GOVERNMENT UNITS}

Changing life habits and accepting an active lifestyle where significant physical activity should be important, primarily in the function of preserving health, working abilities and vitality, is a long-term process in which an individual and family and local self-government and a comprehensive society must act together. For now, there is the publicly declared readiness of the state registered, which through the Strategy for the Development of Sport has recognized that there is a problem, according to which, as the first priority, the increase in the scope of sports for all citizens has been raised. With this document, recreational sports get wider political support for their so- cially responsible activities. The profession recognizes that the largest number of recreational players in Europe and Serbia are defined as independent exercises outside of classical sports organizations Electronic social networks as a new form of social consciousness formation have become a way of gathering minded people and forming civic initiatives for building bicycle paths and engaging in individual modalities of exercise, such as running, Cross Fit and so on. In this direction, with the aim of becoming mass sports, open-air stands are being built, trim paths, health paths, biking trails, hiking tours, wider pedestrian zones, parks are being improved....

Trim polygons have experienced a new "youth" so today they are built by many local self-governments, socially responsible companies, donated by athletes... all with the idea that outdoor exercises are places for fostering the habit of regular exercise and gathering enthusiasts and interested citizens.
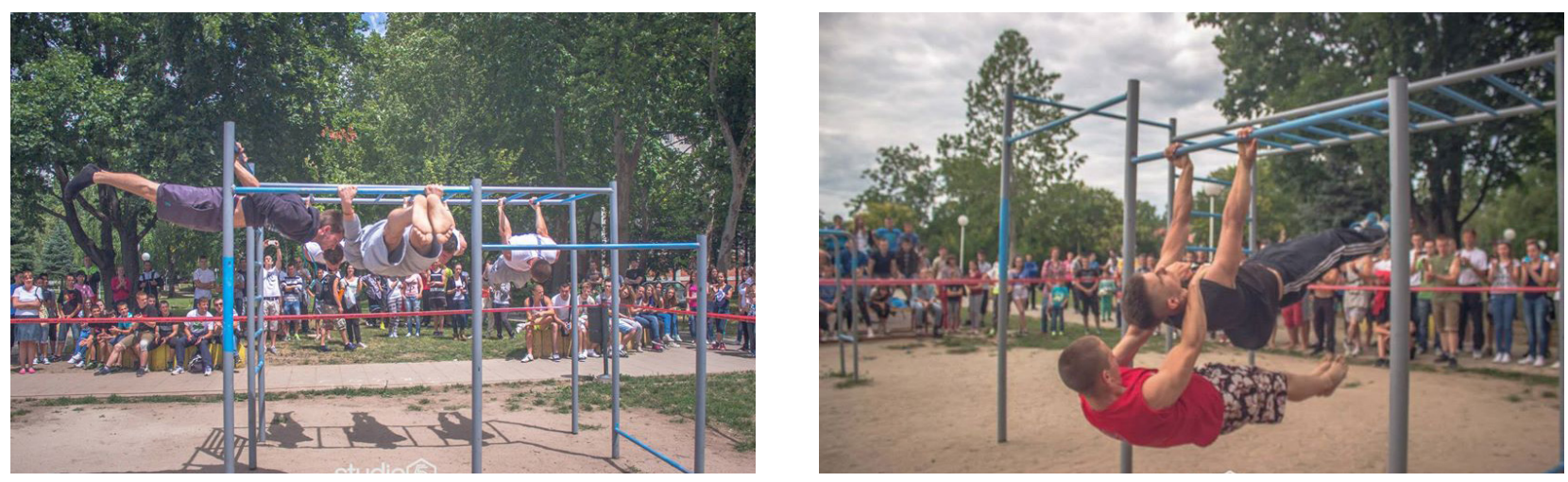

Photo 1. Open exercise ground (the City of Sombor, 2015)

\section{CAMPAIGN AND PROGRAM (PRE) DESIGN OF RECREATIONAL ACTIVITIES}

From the field of manifestations and actions "Healthy and capable" movement that has grown into "Sport for All" which basically promoted exercising for health reasons, has been in Serbia for years. Today, this movement is a model of good practice through which projects are financed from budget funds, primarily from local self-government, few interested sponsors, and sometimes as part of projects of international organizations, such as TAFISA, ISCA, etc.

As examples of good practice in Serbia, recognizable actions and manifestations that have been successfully implemented by the mentioned associations and societies in the field of sports for all have been carried out successfully for years (Table 2). 
Table 2. Programs and campaigns aiming at promotion of recreational activities

\begin{tabular}{|c|c|c|}
\hline & Program title & Exercise description - goal of the activity \\
\hline 1968 & EXPO-ZIM & $\begin{array}{l}\text { The international fair event of the first weekend in December, which gathers over 15-18 } \\
\text { thousand visitors }\end{array}$ \\
\hline 1972 & $\begin{array}{l}\text { HEALTHS, SPORT AND } \\
\text { RECREATION DAY }\end{array}$ & $\begin{array}{l}\text { Public fights, dance, aerobics, interviews with athletes, actors, politicians, as well as } \\
\text { occasional competitions in orienting movement, team sports }\end{array}$ \\
\hline 1972 & PROMOTIONAL EXCURSIONS & Bicycle, bus or hiking \\
\hline 1990 & WORLD HIKING DAY & It has been organized since the beginning of the ' 90 s, it is realized in mid-October \\
\hline 1991 & $\begin{array}{l}\text { SUMMER RECREATION } \\
\text { FESTIVAL }\end{array}$ & $\begin{array}{l}\text { An event that promotes a healthy lifestyle and gathers fans of an active way of life and a } \\
\text { relationship with yourself and the environment }\end{array}$ \\
\hline 1993 & CHALLENGE DAY & $\begin{array}{l}\text { To determine which is a "sportier” city in Serbia, or in which environment the „sport in } \\
\text { leisure" is present as one of the criteria for development of participation in sports }\end{array}$ \\
\hline 1993 & YU SKI FEST & $\begin{array}{l}\text { International Winter Sports Recreational and Snow Sports Competition, Professional and } \\
\text { Educational Programs and Social Entertainment Activities }\end{array}$ \\
\hline 2000 & $\begin{array}{l}\text { WINTER FESTIVAL OF } \\
\text { CHILDREN RECREATION }\end{array}$ & $\begin{array}{l}\text { The festival is intended for students from } 10 \text { to } 14 \text { years, so far it was held at Divčibare, } \\
\text { Tara, Zlatibor and Kopaonik. On the basis of public participation records, participants } \\
\text { receive diplomas }\end{array}$ \\
\hline 2005 & WORLD DAY WITHOUT CARS & $\begin{array}{l}\text { Traditional manifestation of mutual incentives for smaller use of cars in transport to } \\
\text { work, above all, promotion of walking and cycling for all distances shorter than } 3-5 \mathrm{~km}\end{array}$ \\
\hline 2010 & DAY WITHOUT ELEVATORS & $\begin{array}{l}\text { Joint action of all members of the association, socially responsible companies, institutions } \\
\text { that support healthy lifestyles and reduced use of elevators and escalators, which are } \\
\text { symbolically out of use on that day }\end{array}$ \\
\hline 2012 & $\begin{array}{l}\text { EUROPEAN DAY OF SPORTS } \\
\text { CHALLENGE }\end{array}$ & $\begin{array}{l}\text { The European Union finances appropriate promotional campaigns and events last } \\
\text { weekend in September }\end{array}$ \\
\hline 2012 & FLASH MOB & $\begin{array}{l}\text { Group choreographies and joint promotional public exercises that are announced, } \\
\text { published and commented primarily on social networks }\end{array}$ \\
\hline 2014 & $\begin{array}{l}\text { EUROPEAN INNITIATIVES IN } \\
\text { SERBIA }\end{array}$ & $\begin{array}{l}\text { European Time of Physical Education, European Week of Fitness, European School } \\
\text { Sports Week }\end{array}$ \\
\hline
\end{tabular}
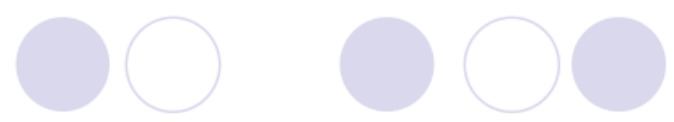

Local Community on World Challange Day in Serbia from 1993-2016
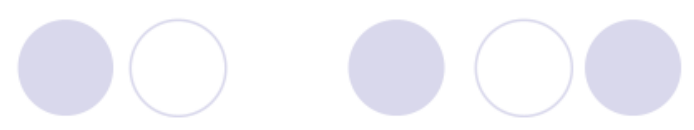

Participants on World Challange Day in Serbia from 1993-2016

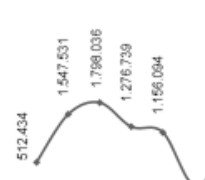

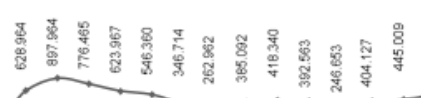

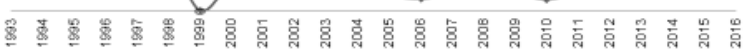

Chart 3 Response of the citizens of Serbia and participation on World Challenge Day (1993-2016) 
Chart 3 shows the increase in the number of participants in the Challenge Day in the past 24 years. Besides, this program was also an "expert polygon" for the realization and evaluation of a large number of models of encouraging citizens to participate in physical activity (day of open doors, lottery, day recorder, mini tournaments and the like). The activities listed in Table 2 can be classified into health promotion exercises. Without pretensions to list all, somehow, an internationally recognizable brand, they deserve to be named and to show in this way respect for duration, range, significance, organization:

- Cross of the publishing houses of Politika and Borba belongs to manifestations with the longest tradition that has survived to this day in a somewhat modest and even today in the competitive form;

- Cross RTS in cooperation with the Ministry of Education, Science and Technological Development is the most numerous because at the same time it is being realized in all schools in Serbia;

- The White Stream was launched in '73. and is regularly held at the end of January, gathers athletes competing and those who love running;

- Fruška Gora Marathon gathers fans of orienteering and competition in nature for more than four decades;

- Since 1988, Belgrade has entered the family of cities that organize a marathon race with its Fun Race, which gathers thousands of recreational players;

- "Circle the Circle and Be My Friend", at the beginning of the '90s, the Athletic Club of Rakovica started at Ada Ciganlija as a promotional race organized during spring and autumn every month. There is a List of recorders by gender and by age, aged 4 to 84 ;

- "Street Basket" as a competition system replaced the former competitions called "Kids From My Street" and takes place under the supervision of a basketball organization and non-governmental organizations that become an inevitable part of the funding method after 2000. We have noticed that we are in the new format of the competition in basket 3 to 3 on all three held competitions won the highest medals.
In addition to the existing organizations in the recreational sports system, as a need to meet the challenges of modern society, there is an increased interest and participation of health institutions. Thus, the Batut Institute launches a national health campaign called "Your Heart in Your Hands" during which, through a series of promotional lectures and expert meetings, health workers are trained for preventive activities in dealing with citizens.

The National Education Council has adopted measures to improve the health of children and youth by improving the teaching of physical education. The document was prepared by the Interdepartmental Working Group where the representatives of the Ministry of Education, Science and Technology, the Ministry of Health, the Ministry of Youth and Sports, the Association for School Sports, the Teachers' Faculties of Serbia, the Institute of Sport and Sports of the RS, the Physical Education Pedagogical Society Serbia, the Institute for the Promotion of Education, the Institute for the Evaluation of the Quality of Education, the Faculty of Sport and Physical Education of the University of Belgrade, the Standing Conference of Towns and Municipalities, the Union of Teachers of the Republic of Serbia. Inter-agency cooperation has continued, so we can see that all ministries, each in their own domain, have persisted in finding solutions for defined directions of action, as follows:

- The Ministry of Education, Science and Technological Development has included school sports competitions in the calendar of activities. The "School Sports Week" was entered into the Law, and the current Ministry formed a new way of organizing and realizing the selected sport for students of the $5^{\text {th }}$ grade.

- The Ministry of Youth and Sports has proclaimed sports facilities in the Sports Law of 2013 for sports facilities, thus creating a legal basis for the construction, reconstruction and equipping of sports funds MOS and JLS. Also, the 2016 Education Law promulgates for sports organizations and thus creates a legal basis for applying for program resources to JLS.

The Association for School Sports since 2011 started to receive more funds for school sports competitions and new program activities. Since 2013, the project "Sport in schools" has begun in 88 municipalities, and besides, Smederevo, as an example of good practice, hires another $40 \mathrm{PE}$ teachers to implement the program. 
The permanent conference of cities and municipalities with MOS organizes the National Sports Conference in JLS, a series of workshops in the districts and with the support of the Swiss government finances the creation of three sports and sports finance manuals in the JLS.

The Action Plan for the Implementation of the Strategy for the Development of Sport for the period 2014-2018, in addition to the system of school sports competitions, recognizes and defines out-ofschool activities as forms of instruction that can be co-financed by a line ministry or JLS. The description of this program highlights: sports section "per child", course forms of instruction, summer, winter, recreational sports camps, new models of SPRET based on evaluation of participation, weekend and break in the school yard, and the like. It is important to point out that this Action Plan has been taken over by over 130 JLS, who have made their own sports development programs.

\section{VERTICAL ORGANIZATION AND PROGRAM FINANCING OF RECREATIONAL SPORT}

The Law on Sports distinguishes between federations for a certain branch of sport (branch sports associations), sports associations for recreational sports, or associations for sports in institutions (school and university sports, sports in the army, sports in the police, etc.). As recreational sports and sport in institutions do not belong to the sport in a narrow sense, it was necessary for the Sports Strategy to provide models of organization that would connect organizations within recreational sports, or organization of sports in institutions. Linking is a prerequisite for mass sport, organizing competitions and developing sporting activities they belong to.

Through the vertical organization of sports, the law directs the constitutional category as the right of all citizens to be engaged in sports. It specifically emphasizes the obligation of local self-government units to acquire and nurture the habits of regular physical activity (the Law on Sports).

Local self-government units have a particularly important place in the implementation of the strategy. The Law on Sports stipulates that the obligation of each local self-government unit is to determine the program of development of sport in its territory that will be in accordance with this strategy, and that the distribution of funds will take into account the criteria prescribed at the republic level and that the whole process will be clear and transparent. The goal of the National Strategy is to narrow the space for the use of the so-called discretionary rights of local leaders who have often been the source of corruption in sports.

The Law on Sports has established program financing for satisfying the needs and interests of citizens in the local self-government unit. The local self-government unit exclusively finances a program that meets the legally defined criteria, needs and interests of the citizens of the community in the current year. According to the Law on Sports, the local self-government unit, through its bodies, regulates more closely the conditions, criteria and manner and procedure of allocating funds from the budget of the local self-government unit, i.e. approval of a program for meeting the needs of citizens in the field of sports in the territory of the local self-government unit and the manner of publishing data on the proposed programs for financing, approved programs and implementation of approved programs. Program funding and program selection criteria include mandatory adoption of rules to regulate the above issues in relation to budget funding.

A stable percentage of sports funding for all at the central government level ranges from 3-5\% of the sports budget, or $15-20 \%$ at the JLS level. This is a model that can guarantee the achievement of citizen involvement in regular and high-quality physical activity.

A significant part of the National Sports budget is allocated to national recognitions to respected athletes and trainers. The remaining part of the budget, its $70 \%$ is determined for the work of national sports organizations with top results. School sport draws about $15 \%$ of the funds, and recreational sports, sports for all and recreational sports, in order to realize the planned increase in the coverage of citizens by sports requires and receives about $5 \%$ of the funds. 


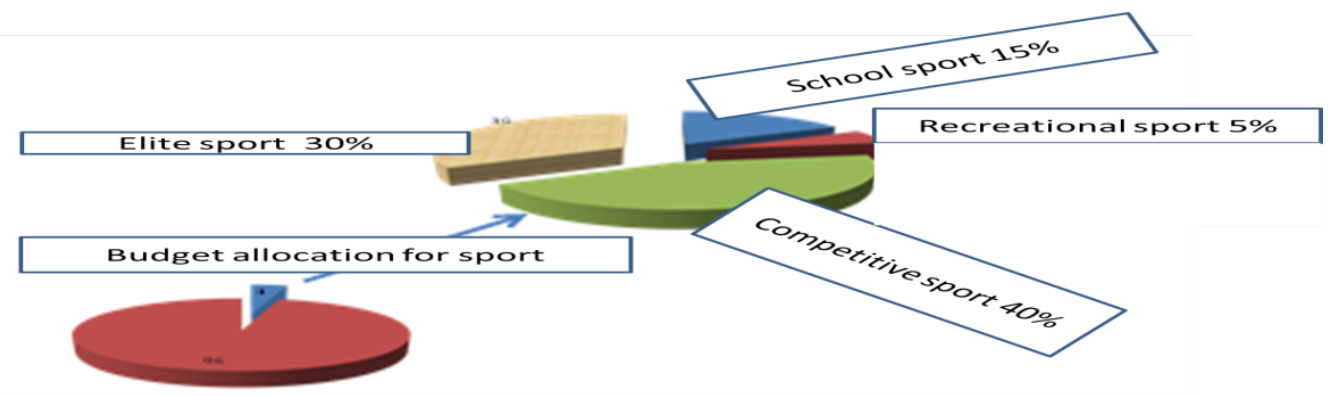

Figure 2. Distribution of budget of the Ministry of youth and sport

The largest volume of activities, defined by the Law on Sports and the priorities of the National Strategy for the Development of Sport, is realized at the level of JLZ. The first step in the implementation of the strategic goals and action plan was to separate the recommended $4 \%$ of the total budget of the JLS for the activity of the entire sport movement. In the next step, it was necessary to redistribute the budget for sports according to the priority areas defined by the National Strategy. Thus, the school sport, which is set much wider by the Strategy, starting from the determination to implement a sports section per child, through course forms of instruction, school sports week, participatory promotional models, vouchers for the practice of high school students and students, weekend in the school yard and the like, defines 20\% of local sports budget. Recreational sports, sport for all, recreational sports to increase the coverage of citizens by sports for health primarily requires a minimum of $15 \%$ of the budget. Competitive sport is still a dominant user with about $60 \%$ of funds. In accordance with the achieved sporting results, some JLZs also support their top athletes through financing the expenses of leasing space for training, work of younger selections and the like.

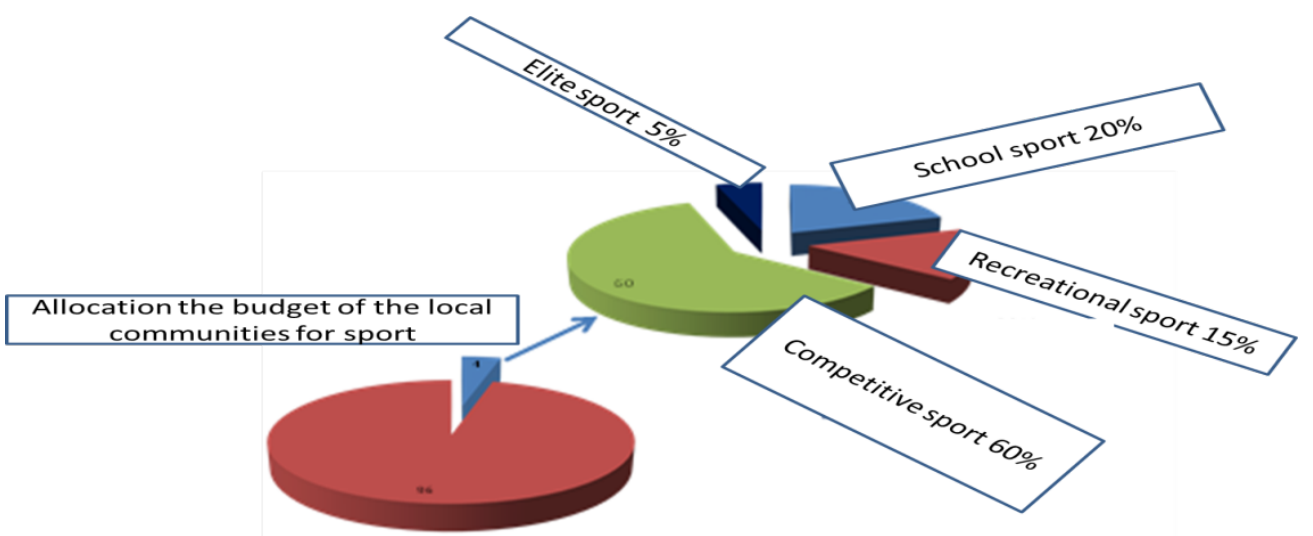

Figure 3. Steps and structure in distribution of budget for sport on the level of local communities

Sport for all is a complex area that includes diverse user groups and their interests. The current practice of allocating funds has resulted in several modalities of programs that can be grouped as: (a) regular exercise programs (during the year), (b) occasional - seasonal activities; and (c) actions and manifestations of a promotional nature. In addition to this, important criteria for evaluating programs that should exclude the encouragement of children and young people to accept regular physical activity, i.e. programs that are able to exclude measures for participation in physical exercise of vulnerable categories of citizens, which include women, unemployed persons, elderly citizens, people with disabilities, etc. 


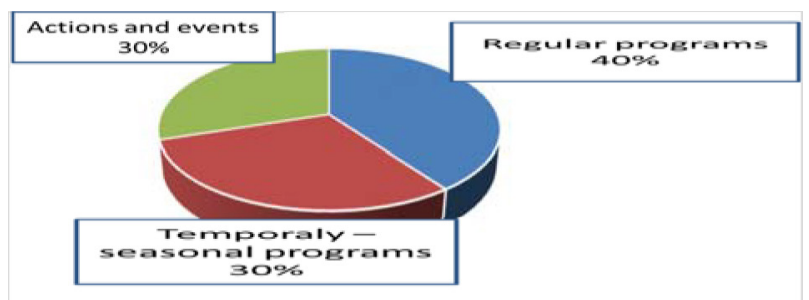

Figure 4 Distribution of assets within the area of recreational sport, sport for all, mass sport

The Law on Sports makes a significant difference between regular - annual and special programs. Special programs do not differ according to their essence - physical activity of citizens, but according to legal entities that can submit them and according to the dynamics of submitting. These are programs financed by funds that are reallocated from the lottery, betting and games of chance profits.

\section{CONCLUSION}

As regular physical activity, sport in a wider sense contributes to the realization of a large number of social goals and values. Gender equality, inter-religious and inter-ethnic understanding and tolerance, equality, equality ... and as a kind of phenomenon is planned and realized as a means of improving the quality of life of individuals, families, local self-government and society.

Since 2006, after several decades of neglect, the mass sport, recreation, sport for all, recreational sport

\section{REFERENCES}

1. Hrčka, J. (1975). Značaj širenja znanja o ulozi sportsko rekreativnih aktivnosti. [The importance of spreading knowledge about the role of sports and recreational activities. In Serbian]. Fizička kultura 1: 35-41.

2. Vuori, I. (1996). Društveni značaj sporta: Zašto i kako sport i fizička aktivnost doprinose javnom zdravlju. [Social significance of sport: Why and how sport and physical activity contribute to public health. In Serbian]. Fizička kultura 4: 341-346.

3. Matić, M. (1991). Rekreacija: u potrazi za sistemskom definicijom pojma. [Recreation: looking for is on the agenda of the society and they have become one of the priorities of realization of the sports movement goals in the Republic of Serbia. This place and importance has been reached with the thoughtful action of the sports movement during the drafting of the Constitution of the Republic of Serbia (2006). These forms of physical activity were found in the Law on Sports, parts of the strategic documents of the development of the Serbian society.

The decade behind us (2006-2016) in the area of affirmation of recreational sport is characterized by the interdisciplinary action of the Ministries of Education, Science and Technological Development; Health; Youth and Sports, together with the Association for School Sports, the Association of Pedagogues of Physical Culture of Serbia, the Institute for Improvement of Education, the Institute for the Evaluation of the Quality of Education, the Faculty of Sport and Physical Education of the University of Belgrade, the Standing Conference of Towns and Municipalities and Civic Initiatives by which all listed actors strive to creating an environment with regular physical activity, exercise and healthy lifestyles.

\section{Acknowledgement}

The paper represents the result of work on the project "Improvement of the quality and accessibility of education to processes of modernization of Serbia" number III 47008, the realization of which is financed by the Ministry of education, science and technological development of the Republic of Serbia (2011-2018). a system definition of a term. In Serbian]. Fizička kultura, 4: 290- 297.

4. Matić, M.(1992). Rekreacija-alias nemir(enje). [Recreation-alias restless(ness). In Serbian]. Godišnjak: 4:144-152.

5. Smodlaka, V. (1996). Fizička aktivnost i zdravlje Izveštaj "Surgeon General". [Physical Activity and Health - Surgeon General Report. In Serbian]. Fizička kultura, 4: 363-365.

6. Rezultati istraživanja zdravlja stanovništva Srbije (2014) [Results of the research on the health of the population of Serbia. In Serbian]. Beograd: Insti- 
tuta za javno zdravlje Srbije „Dr Milan Jovanović Batut"

7. Pokrajac B. (1992). Psihološki smisao rekreacije. [Psychological meaning of recreation. In serbian]. Godišnjak, 4:188-193.

8. Đurđević, N., Mitić, D., Atanasov, D., Vujović, B. (2014). Sport u jedinicama lokalne samouprave Priručnik za finansiranje programa razvoja sporta. [Sport in local government units - Handbook for financing sports development programs. In Serbian]. Beograd: Stalna konferencija gradova i opština - Savez gradova i opština Srbije,

\section{Documents}

1. European Commission/EACEA/Eurydice, 2013. Physical Education and Sport at School in Europe

2. European Opinion Research Group 2003.

3. Zakon o sportu Republike Srbije (2016). [Law on Sports of the Republic of Serbia. In Serbian]. Službeni glasnik RS 10/2016

4. Obrazloženje Predloga Zakona o sportu Republike Srbije (2013). [Reasoning the Proposal of the Law on Sports of the Republic of Serbia. In Serbian]. Minisarstvo omladine i sporta.

5. Smodlaka Vojin - pismo od 11. IX 1995. [Smodlaka Vojin - letter of 11th of September 1995. In Serbian].
6. Startegija razvoja sporta u Republici Srbiji 2014.d o 2018.g.. Poglavlje: Strategija razvoja školskog sporta 2014-2018. [Strategy for the Development of School Sports 2014-2018. In Serbian], Beograd: Ministarstvo omladine i sporta.

7. Strategija razvoja školskog sporta u AP Vojvodina 2013-2017. [Strategy of development of school sport in AP Vojvodina 2013-2017. In Serbian]. Novi Sad: Pokrajinski sekretarijat za sport.

8. Strategija i akcioni plan razvoja školskog sporta $\mathrm{u}$ Autonomnoj pokrajini Vojvodini za period 2013-2017. [Strategy and Action Plan for the Development of School Sports in the Autonomous Province of Vojvodina for the period 2013-2017. In serbian]. Novi Sad: Pokrajinski sekretarijat za sport.

9. Uredba o Nacionalnom programu prevencije, lečenja i kontrole kardiovaskularnih bolesti u Republici Srbiji do 2020. godine. [Regulation on the National Program for the Prevention, Treatment and Control of Cardiovascular Diseases in the Republic of Serbia until 2020. In Serbian]. Dostupno na:

10. http://serbianfood.info/publications/Uredba_o_ nacionalnom_programu_prevencije_2020/ Uredba_o_nacionalnom_programu_prevencije_2020.pdf 


\title{
ПРАКСА МАСОВНОГ СПОРТА И НАЦИОНАЛНА СТРАТЕШКА ДОКУМЕНТА
}

\author{
Душан Митић \\ Факултет спорта и физичког васпитња, Универзитет у Београду, Србија
}

\begin{abstract}
Сажетак
Агенде савременог друштва су испуњене активностима којима се кроз физичку активност и вежбање ради на побољшању квалитета живота појединца, породице, заједнице и целокупног друштва. У многобројним документима стручних, научних али политичких међународних тела и организација, као и документима која су усвојена на нивоу појединачних држава, јавно здравље и активности у циљу промоције здравих стилова живота и пружања могућности свим грађанима да се баве спортским активностим постале су један од приоритета агенди развоја у овом миленијуму. Како у националним, тако и међународним документима и иницијативама, спортска рекреација, уз индивидуалну активност грађана, налази се у сржи стручног напора и политичког деловања са истим циљем, а то је да се кроз омасовљење физичког вежбања дође до здравствених бенефита од значаја за појединца и друштво у целини. Предмет овог рада односи се на документа и праксу вредновања и организовања рекреативног спорта од 2006. године - пуне државне независности Републике Србије. Циљ рада је сагледавање учињеног и позиционирања физичке активности грађана у наредне агенде друштвеног развоја.
\end{abstract}

КљУчне речи: СПОРТСКА РЕКРЕАЦИЈА / ЈАВНО ЗДРАВЉЕ / СТРАТЕГИЈА РАЗВОЈА СПОРТА / СРБИЈА

\section{УВОД}

Физичка активност је основни фактор који доприноси здрављу појединца и популације наводи др Ендрју Ф. Менли (Andrew F. Maneley) у Извештају за „Surgeon General of U. S. (1996)“ и истиче: „Иако је наука о физичкој активности и вежбању човека комплексна област која се још увек развија, данас постоји велики број јаких научно верификованих чињеница и доказа који јасно указују на то да редовна физичка активност и вежбање веома повољно утиче на здравље човека. Агенде савременог друштва су испуњене активностима којима се кроз физичку активност и вежбање, усмерено ради на побољшању квалитета живота кроз афирмацију физичке активности на свим нивоима, од појединца, породице, до организације заједнице, и државе. Како је физичка активност директно повезана са спречавањем болести и преране смрти, као и са одржавањем високог квалитета живота, тако јој се мора посветити исто толико пажње колико се поклања другим питањима здравља од општег друштвеног значаја. На тај начин је физичка активност и физичко вежбање сврстано у оквире процеса унутар којих се налазе здраво окружење, исхрана или коришћење сигурносних појасева и борба против пушења. „Потенцијална вредност физичке активности и физичког вежбања, као начина превенције и мере у очувању здравља повећана је њеном приступачношћу, безбедношћу и могућностима да је прихвати велики број људи“.

Паралелно са закључцима и препорукама сталешких (стручних и научних удружења и организација), прва декада 21. века може се описати и са политичким иницијативама у простору афирмације физичке активности и самог физичког вежбања. Тако, Лисабонска конвенција (1998), Бела књига о спорту (2004), Препорука Светске здравствене организације о исхрани и физичкој активности (2007), као и многа друга документа, резолуције, препоруке... 
биле су политичка утемељења за одлуку ЕУ (децембар 2010) да се до 2020. године нових $100.000,000$ Европљана покрене на редовну физичку активност. Редовна физичка активност је основ за очување и унапређење здравља, а покрет „Спорт за све“ се препознаје као место унутар кога је могућа реализација тих циљева, стоји између осталог записано у наведеним документима, али и изјавама званичника. У наведеним документима, али и документима која су усвојена на нивоу појединачних држава (чланица ЕУ и оних које то нису) јавно здравље и активности у циљу промоције здравих стилова живота и пружање могућности свим грађанима да се баве спортским активностим, један су од приоритета које су препознале и Уједињене нације и њене агенције и уврстиле у светске програме у новом миленијуму.

„Спорт за све“, као покрет цивилног друштва, пружа могућност бављења физичким вежбањем и спортом свих грађана. Реализује се као препорука да се спортске активности упражњавају током целе године и то најмање два пута недељно. „Спорт за све“ је средство у стварању здраве, етичне и радно способне нације (смањењем трошкова лечења, продужењем радног века, здравији и задовољнији запосленици и грађани...).

Како у националним, тако и међународним документима и иницијативама, спортска рекреација, уз активности грађана кроз тренинг и такмичење спортских грана (систем спорта у ужем смислу), образовни систем (сви нивои образовног система), физичко вежбање у инстутицијама и коорпорацијама... налазе се у сржи стручног напора и политичког деловања са заједничким циљем, а то је омасовљењем физичког вежбања доћи до бенефита од значаја за појединца и друштво у целини.

Европски простор се додатно уједињује кроз спорт. Перспективу уједињења целине континента кроз спорт, доносе резолуције министара задужених за спорт, које организује Савет Европе. На састанку из 2011, министри 49 европских земаља препознали су здравствену и социјалну вредност физичког вежбања (физичко вежбање у сврху здравља, социјална укљученост, људска права, демократски развој, регионална политика, култура, образовање, нова радна места, волонтерско организовање...) и определили се за физичко вежбање (спорт) као средство у креирању европске димензије. Полазиште овом документу је била „Бела књига“ (2007) којом је ЕУ препознала значај физичке активности у очувању здравља. У том документу је препоручена изградња јаких везе са здравственим, образовним и системом спорта. Следећи важан документ политичких иницијатива донет на састанку министара Савета Европе (CE) задужених за спорт (2008), на коме је усвојено „Европско упутство за физичку активност“. Овај документ $\mathrm{CE}$ је објединио напоре да се до квалитетније европске перспективе за живот свих грађана дође јачањем веза између здравља, образовања, транспорта и урбаног развоја. Усвајањем Лисабонске деклерације (2009) Европска унија је истакла своје експлицитне компетенције у простору спорта, и по први пут „јако“ уврстила спорт у европску повељу. Дакле, ЕУ и СЕ су политички афирмисали значај и улогу физичког вежбања (спорта) у функцију развоја континента! Поставља се питање шта и како су радиле струка и политика у Србији у назначеном периоду, од године њене пуне државне незавиност (2006). Предмет овог рада односи се на документа и праксу вредновања и организовања рекреативног спорта од године пуне државне независности Републике Србије. Циљ рада је сагледавање позиционирања физичке активности грађана у функцији здравља и актуелна организованост масовног спорта у Србији у односу на паневропске идеје и документа.

\section{СМИСАО МАСОВНОГ СПОРТА - ЈЕДИНСТВО РЕКРЕАЦИЈЕ И СПОРТА}

Трагање за дефинисањем масовног спорта је у суштини трагање за смислом физичке активности и самог вежбања свих грађана. На том путу први корак је дефинисање значења појма „РЕКРЕАЦИЈА”. Разлажући тезу Благајца да „Спортска рекреација представља културан, физички активан и здрав начин живота", Матић (1991. стр. 286) каже да је то... акција испуњена одређеном активношћу... односно да рекреација представља особени допринос управљању сопственим животом". Матић (1992) говори о рекреацији као стварању бића... односно да рекреација представља „НАПОР ЗА ПОСТИЗАҢЕ СЕБЕ”. 
Из угла психолога, који годинама истрајава на редовном подневном трчању „рекреације ради”, Бранко Покрајац указује на чињеницу да се психолози мало баве добробитима и позитивним аспектима и ефектима рекреације код здравих особа и да се појам срећа тешко проналази у анализама. Он промовише идеју да „рекреациони спорт (или рекреација телесним вежбањем) буде планска активност којом се, тежи унапређењу или одржању физичке и психолошке добробити човека; „рекреација је обнављање телесних и менталних моћи“. Стање у које доспева учесник рекреације је „Дубљи доживљај среће, који се не јавља у било каквој јурњави, него само ако је човек везан за активност, ако је опажа као релевантну за нека својства или способности које су ближе центру његовог Ја-концепта“. (Покрајац, 1992).

Признати научник и један од првих професора београдског ДИФ-а, др Смодлака каже: „Рекреација је покрет најразноврснијих активности с циљем да подигне радну способност, квалитет живота и опште емоционално стање, радост живота"(Смодлака, писмо од 11. 09. 1995)

„Емоционална добробит“ - „здрав начин живота“, „напор за постизање себе“ у условима „радног друштва слободног времена“ (коме очигледно тежимо), представља полазиште за наше даље сагледавање особа које имају свој програм рекреације.

Уважавајући чињеницу да је тачка ослонца рекреације њен однос према окрепљењу освежењу - припреми за нови рад и квалитетнији живот, уочава се да су опредељења и улагање појединца и друштва у рекреативне пројекте, како по обиму и интензитету, тако и по издвојеним финансијама..., превазилазе оне које су регистроване у прошлом веку, на почетној степеници њеног савременог поимања. Стога, реална претпоставка за одвијање рекреације јесте спремност улагања у програм за развој сопствене личности!

Рекреативно бављење спортом, у складу са стандардима и препорукама ЕУ, је оно бављење које се реализује редовно (минимум једном недељно), по квалитетним програмима, под вођством стручних лица, на за то адекватним спортским објектима и уз одговарајућу лекарску контролу.

Спорт се са друге стране мора посматрати двојако, (и) као средство физичке активности и физичког вежбања човека, (и) као спорт у ужем смислу, односно тренинга и такмичење. Он he ce у овом раду анализирати искуљчиво као средство које обогаћује природу човека да буде физички активан. Спорт као физичко вежбање доприноси личном и друштвеном развоју, он је средство задовољења човекове потребе за физичким вежбањем ради личног физичког и менталног благостања. Савремене студије афирмиршу спорт, самим тиме и физичко вежбање човека кроз бенефите у простору интелектуалног, социјалног, афективног, психолошког, биолошког и моторичког значаја. Стога, спорт је посебно вредан за савременог човека и свет који се брзо мења и који се, с једне стране, карактерише повећањем слободног времена, а с друге стране урбанизацијом и сталним технолошким развојем који теже да одвоје човека од његовог социјалног окружења и премести га у виртуелни свет друштвених мрежа и догађања.

Редовна физичка активност, спорт и рекреација могу да одиграју важну и активну, конструктивну улогу у јачању физичког, интелектуалног и моралног здравља становништва. Она је један од кључних елемената у достизању хуманих вредности и у акцијама које се спроводе против различитих предрасуда, дискриминација и идеја насиља. Физичка активност и спорт доприносе социјалној кохезији, превазилажењу предрасуда, повећању позитивног утицаја на јавно мњење и ширење етичких и општих принципа који се кроз њега преносе. Сразмерно наведеном значају физичке активности и спорта, њихова афирмација и развој морају бити подржани и охрабривани на свим нивоима друштва од породице и локалне заједнице до националне државе.

\section{РЕКРЕАЦИЈА У ЗАКОНСКИМ И СТРАТЕШКИМ ДОКУМЕНТИМА ОД ЗНАЧАЈА ЗА РАЗВОЈ ДРУШТВА И СТРУКЕ}

Како данашња пракса у Србији показује, држава брине и о организованости друштва кроз физичку активност и физичко вежбање. До оваквог односа прошао је цео век који се може описати са два периода, од којих први припада Србији, као делу једне од државних заједница (КСХС; КЈ, ФНРС; СФРЈ; СРЈ; СЦГ), односно другом периоду који се одвија од јуна 2006. године 
од када траје државна независност Републике Србије. За целовиту анализу по предмету овог рада, интересантан је период након Другог светског рата, од педесетих година прошлог века до 2006. године, који је био обележен државном бригом о физичком васпитању, спорту и масовном спорту. Због потребе доказивања успешности функционисања модела социјализма током периода ФНРЈ - СФРЈ посебно се улагало у развој спорта који је годинама то и оправдавао. Поред бриге о врхунском спорту, тадашња држава је водило рачуна и о осталим регистрованим спортистима и масовним облицима физичке културе. Друштвена превирања и транзиција која је започела средином осамдесетих година, значајно је утицала и на укупан однос државе према рекреацији грађана.

Први Закон о спорту Републике Србије донет je 1996. године. Овај закон се, у терминолошком и суштинском смислу, бави само спортом, док је рекреација грађана постала практично брига појединца, без озбиљније подршке друштва. Спортски систем, нарочито његов међународни ниво, који је био под санкцијама (1992-1996), и који је изгубио своју видљивост али и резултатски значај који је имао у претходним периодима, почиње да се одвија кроз два процеса, и то: први, кога прати опадање интересовања, гашење појединих спортских грана, институција, публикација и слично, и други, кога описује одрицање од аутономије спорта која се може описати прилагођавањем и функционисањем спорта ускладу са интересима државе. Наведено, у комбинацији са продуженом економском кризом и санкцијама, довело је до неке нове вредносне оријентације спортског покрета који се може описати гашењем аматеризма и волунтаризма у спорту у најширем смислу.

Формирање Министарства омладине и спорта (2007) довело је до израде и усвајања прве, а потом и друге владине стратегије развоја спорта у Србији. Прва стратегија која је покрила период од 2009-2013. и Закон о спорту из 2009. су креирали окружење са предвидивим условима за развој спорта у најширем смислу. Тежиште прве стратегије је било према спорту деце и омладине, развоју врхунског спорта и ревитализацији и грађењу спортске инфраструктуре. Закон о спорту и пакет усвојених подзаконских аката су усмеравали развој и финансирања спорта на основу два критеријума, први је спортски резултат у датој спортској грани, док се други односи на програмску оријентацију матичног спортског савеза.

Стратегија развоја спорта у Републици Србији за периоду од 2014. до 2018. као приоритет поставља повећање обухвата грађана који имају редовну физичку активност, те развој школског спорта и спортске инфраструктуре. На тај начин Република Србија се приближава европском систему вредности који каже да се стање једне нације у погледу спорта огледа у томе колико та земља брине о сваком грађанину и стварању услова да се сви баве спортом.

ПремаЗаконуоспортуРепубликеСрбије(2016), подстицање и стварање услова за унапређење спортске рекреације, односно бављење грађана спортом представља приоритетну област потреба и интереса друштва. Закон регулише да свако има право да се бави спортом, и да бављење спортом мора бити хумано, слободно и добровољно, здраво и безбедно, доступно свим грађанима под једнаким условима без обзира на узраст, ниво физичке способности, степен евентуалне инвалидности, пол и друго лично својство. Забрањена је свака дискриминација у спорту! Јавне власти свих нивоа су одговорне, било директно или оспособљавањем других, за побољшање приступа спорту и спортским капацитетима свих грађана, без обзира на њихово социјално порекло, економски статус и приходе, узраст, пол или етичку припадност. Спорт не сме да буде ексклузивно право заштићених категорија, већ доступан свим грађанима! Ови наводи из Закона о спорту су утемељени на Уставу Републике Србије (2006), који на више места наводи спорт, физичку културу и физичко вежбање грађана чиме их уводи у уставну категорију. Мора се истаћи да је те 2006. године, било врло важно то што је струка спорта у најширем смислу препознала, осмислила и лобирала у корист дефинисања физичке активности грађана у Уставу Републике Србије као независне државе.

Сходно уставним и законским одредницама, јавне власти свих нивоа организације државе, обавезне су да израдом стратегија и програма развоја спорта и финансирањем програма у области спорта доприносе реализацији циљева који су јасно дефинисани Законом о спорту, како оном из 2011. тако и последњим из 2016. године. 
Оба закона прописују подстицање и стварање услова за унапређење спортске рекреације, односно бављење грађана спортом, посебно деце, омладине, жена и особа са инвалидитетом, али и изградњу, одржавање и опремање спортских објеката, едукацију, информисање и саветовање грађана, спортиста и осталих учесника у систему спорта о питањима битним за одговарајуће бављење спортским активностима и делатностима.

Закон о спорту из 2016. године, у члану 3. став 3 дефинише да спортска рекреација (рекреативни спорт, спорт за све, масовни спорт) јесте област спорта која обухвата добровољно бављење физичким вежбањем, односно спортским активностима ради одмора, освежења, забаве, унапређивања здравља или унапређивања сопствених резултата и ради задовољења потреба за кретањем, игром и дружењем, у свим сегментима становништва.

Следећи важан документ за афирмацију законских решења у Републици Србији, односи се на Правилник о спортским гранама из 2016. године. Овим документом кога је потписао министар спорта, дефинисане су гране спорта и и спортске дисциплине у Републици Србији. Међу њима је и спортска рекреација (спорт за све, рекреативни спорт, масовни спорт): у обе конкуренције (жене и мушкарци свих узраста). Циљеви спортске рекреације се реализују кроз планирање и спровођење образовно-васпитних активности са децом, омладином и одраслима.

Последњим и претходним законом олакшана је могућност препознавања и регистровања нових спортова, формирање клубова и савеза. Законске измене су омогућиле да се за непуну декаду утростручи број регистрованих спортова и спортских савеза. Оно што је важно истаћи, као српску специфичност, у овом процесу је прихватање тенденција повећаног учествовања жена у спорту, па се тако и код нас повећао број спортова и дисциплина у којима се такмиче жене. Жене су постале застуљеније и у олимпијским делегацијама, а 50\% медаља са последњих ОИ у Рију (2016) освојиле су жене.

\section{РЕДОВНА ФИЗИЧКА АКТИВНОСТ ГРАҚАНА - НАЦИОНАЛНИ ИЗАЗОВ И СТРАТЕШКИ ПРИОРИТЕТ}

Светска здравствена организација (С3O, енг. WHO) од свог оснивања покушава да кроз „отворена писма“, упућена свим владама света, укаже на позитивне ефекте редовне физичке активности код свих структура грађана. Истиче да недовољна физичка активност, евидентна у свакодневном животу и раду, посебно њен изостанак, угрожава предшколску децу, адолесценте, особе изложене стресним ситуацијама, жене, особе у трећем добу и особе које болују од хроничних незаразних болести (гојазност, хипертензија, дијабетес мелитус, остеопороза...). Недовољна физичка активност или хипокинезија, како се уобичајено назива, проглашава се за самостални фактор ризика по живот наведених категорија грађана (Вуори, 1996).

Лични режим живота и животни стил имају $50 \%$ важности за здравствени статус тврди Хрчка, (Hrcka, 1990). Здрав начин живота, који подразумева режим живота, рада, здраво окружење, режим исхране, одмарања и читав низ слободновременских активности у којима може да доживи самопотврђивање, очигледно није само проблем појединца, јер угрожавањем појединца ремети се стабилност породице, а преко ње и шире друштвене заједнице.

Подаци истраживања Еуробарометра из 2002. указују да је две трећине одрасле популације у земљама Европске уније (ЕУ) физички недовољно активно за достизање оптималне здравствене користи (European Opinion Research Group 2003). Такође, због напретка технологије и описаних социјалних промена, физичка неактивност постаје све већи проблем за децу и омладину.

Према подацима истраживања Института за јавно здравље Србије „Др Милан Јовановић Батут” у Републици Србији (Табела 1) гојазан је скоро сваки пети одрасли становник (18,6\%), сваки трећи становник конзумира цигарете $(33,6 \%)$, око $40 \%$ свакодневно или повремено конзумира алкохол, а скоро половина становништва има хипертензију (46,5\%). 
Табела 1 Учесталост обољења или стања становништва узраста 20 и више година, Србија, 2000, 2006 и 2013. година.

\begin{tabular}{|c|c|c|c|}
\hline \multirow[t]{2}{*}{ 06ољењa/стања } & 2000 & 2006 & 2013 \\
\hline & $\%$ & $\%$ & $\%$ \\
\hline Повишен крвни притисак (хипертензија) & 19,7 & 23,1 & 33,2 \\
\hline $\begin{array}{l}\text { Деформитет доње кичме или други хронични проблем } \\
\text { са леђима (бол у леђима) }\end{array}$ & 18,0 & - & 20,3 \\
\hline $\begin{array}{l}\text { Вратни деформитет или други хронични проблем са вратном } \\
\text { кичмом }\end{array}$ & 4,6 & 8,0 & 13,9 \\
\hline Повишена масноћа у крви (холестерол) & 5,7 & 8,0 & 13,0 \\
\hline $\begin{array}{l}\text { Артроза - дегенеративно обољење зглобова } \\
\text { (без артритиса - запаљење зглобова) }\end{array}$ & 5,0 & & 11,0 \\
\hline Коронарна болест срца или ангина пекторис & - & - & 9,9 \\
\hline Алергија (6ез алергијске астме) & - & 5,3 & 8,9 \\
\hline Шећ̆ерна болест (дијабетес) & - & 5,3 & 8,1 \\
\hline Депресија (или хронична анксиозност) & 4,6 & 6,0 & 6,7 \\
\hline
\end{tabular}

Истраживање овог Института и Министарства здравља из 2013. године показало је да се физичком активношћу, спортом или спортском рекреацијом најмање три пута недељно бавило 8,8\% становника. Физичком активношћу, намењеној јачању мишића, најмање три пута недељно, у 2013. години се бавило 4,8\% становника Републике Србије.

На основу лонгитудиналних популационих студија праћења телесне масе, у Републици Србији је у 2013. године регистровано $40,4 \%$ оптимално ухрањеног становништва. Више од половине становништва је прекомерно ухрањено (56,3\%), од чега се њих $35,1 \%$ разврстава у предгојазну, односно $21,2 \%$ у групу гозајних. У Републици
Србији се, између два истраживања, 2006. и 2013. години, региструје значајно повећање процента гојазног становништва (са $17,3 \%$ на $21,2 \%$ ). Исто истраживање доноси и тренд пораста проблема хроничних незаразних болести (Табела 1). Евидентан је пораст особа са хипертензијом са $23,1 \%$ на $33,2 \%$. Повишене масноће у крви (укупни холестерол) се увећао са $8 \%$ у 2006. године на $13 \%$ популације у 2013. години. У порасту је број појединаца који болују од неког типа шећерне болести (од 5,3\% на $8,1 \%$ ).

У истом периоду, од 2006. до 2013. године, региструје се пораст дечије гојазности $(2,6 \%$ на $4,9 \%)$ (График 1)

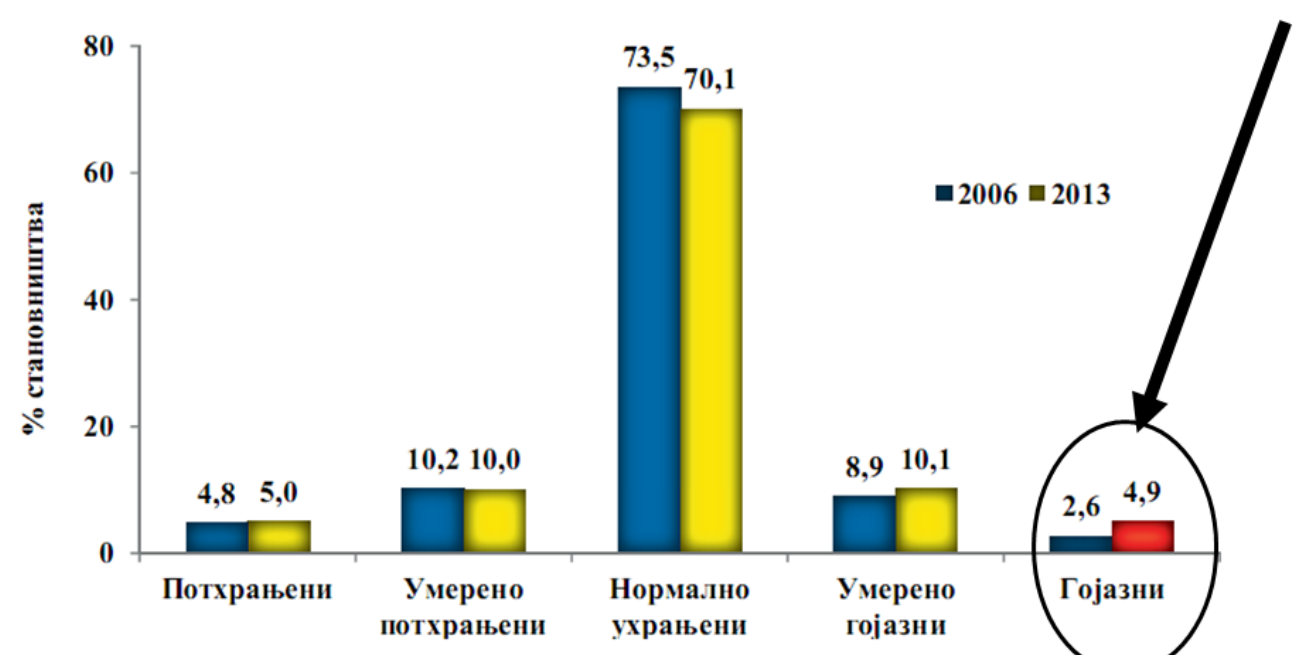

График 1 Ухрањеност деце и младих узраста 7-14 година, Србија 2006. (плаво) и 2013.(жуто) године 


\section{Већим обухватом грађана до реалиације стратешких циљева масовног спорта}

Циљеви Стратегије спорта су да област спорта за све, рекреативног, масовног спорта и спортске рекреације обухвати читаву популацију. У односу на овај циљ, за сада не постоји систематско праћење садржаја и активности у којима учествују грађани, јер највећи број њих, као и у читавој Европи, самостално себи организује и реализује неки облик физичког вежбања - активности.

Један од извора у евалуацији обухвата грађана физичком активношћу могу бити подаци које периодично доноси Министарство омладине и спорта. Тако, ако се претпостави да увећање броја организација прати и увећање обухвата становништва, према критеријуму, као што је назив саме организацие, долази се до закључка да су најзаступљеније спортске организације у простору фудбала, кошарке, каратеа, одбојке и спортске рекреације (рачунајући заједно рекреативни спорт и спорт за све). По овим подацима, фудбалу припада $16,92 \%$ свих организација или њих 3047, кошарка има 811 организацију (4,50\%); карате - $750(4,17 \%)$; одбојка - 643 (3,57\%). Од спортских организација које заједно чине корпус организација рекреативног спорта, региструје се 638 организација које у називу имају фитнес (3,54\%), док у спортском риболову има 606 регистрованих организација. Под називом рекреативни спорт има 567 организација; боди билдинг носи назив њих 337; аеробик - 223; плес (спортски, модерни) 249; планинарство - 241; аеробик - 223; спорт за све - 201; аикидо - 213; јога - 169; боћање - 72; оријентиринг - 67; раднички спорт - 61; традиционални спортови - 41; мулти спортови 241. Обухват грађана се шири преко спорта особа са инвалидитетом са 93 организације, спорт особа са инвалидитетом, глуви и наглуви са 24 ; соколски спорт носи 19 организација; сеоски спорт - 18; спорт особа са инвалидитетом, слепи и слабовиди - 17; спорт особа са инвалидитетом, специјална олимпијада - 13; док 10 организација се бави спортом у дијаспори.

Континуирана праћења и мониторинг су заживели и у Србији (график 2). Када се пореде резултати упитника о учесталости бављења рекреацијом запослених грађана у последњих десет година уочавају се неке прилично стабилне вредности, док се на жалост уочава и пораст броја особа које никада не вежбају, док истовремено опада број оних који најредовније вежбају (3-4 пута недељно) (График 2).

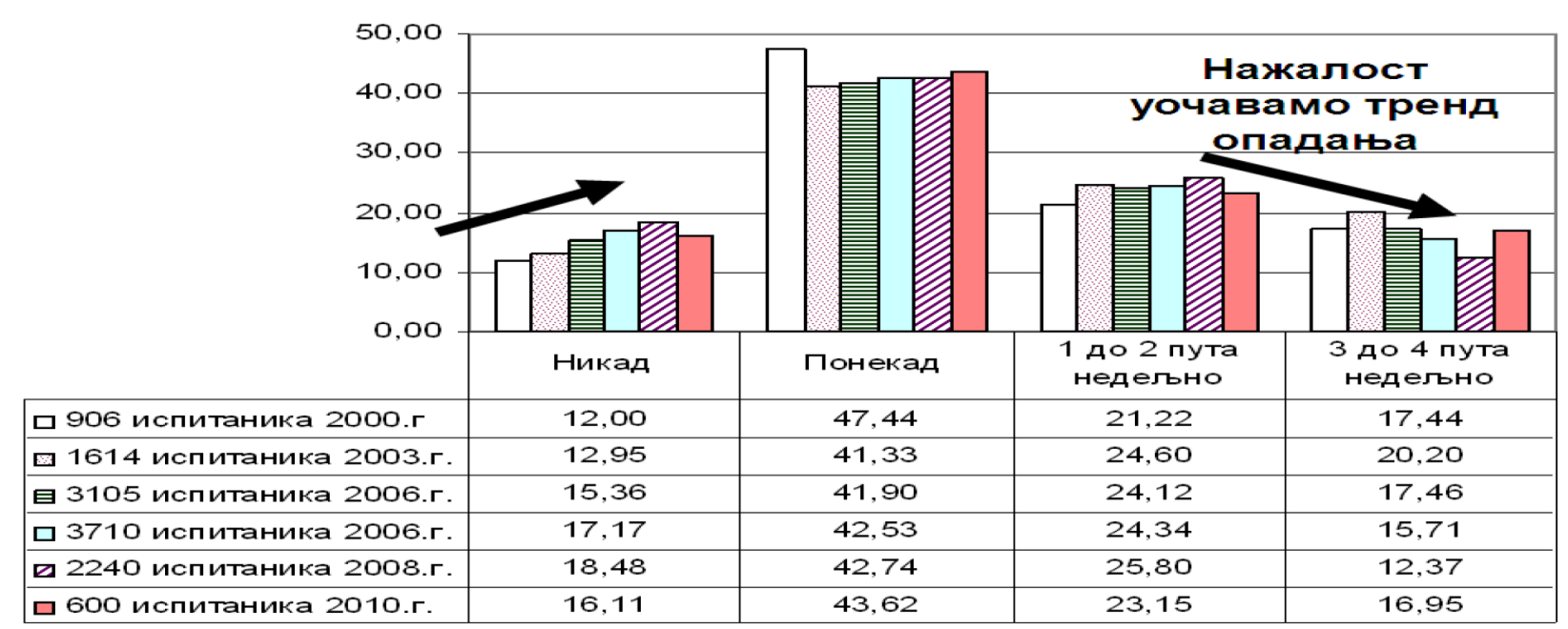

График 2 Бављење рекреацијом запослених грађана у периоду од 2000. до 2010. године 


\section{ВИЗИЈА РЕКРЕАТИВНОГ СПОРТА СРБИЈЕ - ОД ИНИЦИЈАТИВЕ ПОЈЕДИНЦА ДО СТРАТЕШКИХ И ПРОГРАМСКИХ АКТИВНОСТИ ЈЕДИНИЦА ЛОКАЛНЕ САМОУПРАВЕ}

Промена животних навика и прихватање активног стила живљења у коме значајно место треба да има редовна физичка активност, пре свега у функцији очувања здравља, радне способности и виталности, је дуготрајан процес на коме заједно морају да делују и појединац и породица и локална самоуправа и целовито друштво. За сада се региструје јавно исказана спремност државе која је кроз Стратегију развоја спорта препознала да постоји проблем, сходно коме је као први приоритет поставила повећање обухвата бављења спортом свих грађана. Овим документом, рекреативни спорт добија ширу политичку подршку за своје друштвено одговорно деловање. Струка препознаје да се највећи број рекреативаца у Европи и у Србији опредељује за самостално вежбање ван класичних спортских организација. Електронске друштвене мреже су као нови облик формирања друштвене свести и код нас постале начин за окупљање истомишљеника и формирање грађанских иницијатива за градњу бициклистичких стаза и укључивања у поједине модалитете вежбања, као што су трчање, кросфит (Cross Fitt) и сл. У том правцу, а са циљем омасовљења, граде се вежбалишта на отвореном, уређују се трим стазе, стазе здравља, бициклистичке стазе, планинарске туре, шире се пешачке зоне, оплемењују паркови....

Трим полигони су доживели нову „младост“ тако да их данас граде многе локалне самоуправе, друштвено одговорне компаније, донирају спортисти...., а са идејом да вежбалишта на отвореном буду места за неговање навике редовног вежбања и окупљања ентузијаста и заинтересованих грађана.
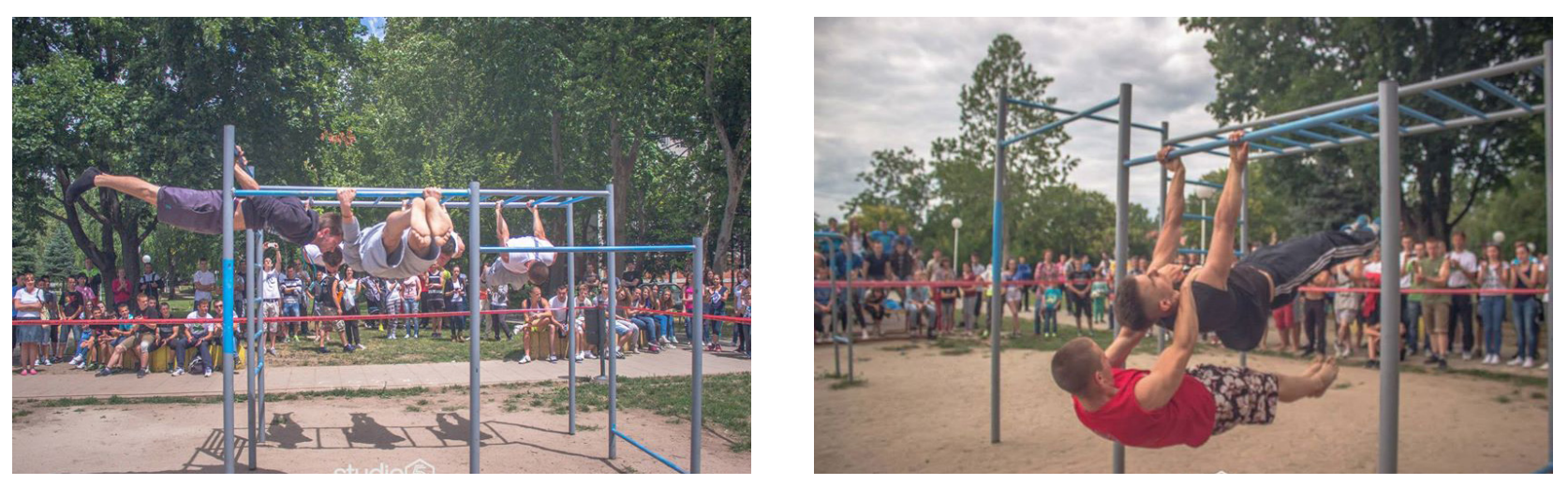

Слика 1 Вежбалиште на отвореном (град Сомбор, 2015)

\section{КАМПАҢЕ И ПРОГРАМСКО (ПРЕ) ОБЛИКОВАЊЕ РЕКРЕАТИВНИХ АКТИВНОСТИ}

Област манифестација и акција које су у основи имале промоцију вежбања ради здравља, у Србији је годинама покривао покрет „Здрав и способан“ који је прерастао у „Спорт за све“. Данас, овај покрет представља модел добре праксе кроз који се реализују пројекти који се финансирају из буџетских средстава, пре свега локалних самоуправа, заинтересованих малобројних спонзора, и понекад као део пројеката међународних организација, типа TAFISA, ISCA и сл.

Као примере добре праксе у Србији одвијају се препознатљиве акције и манифестације које већ годинама успешно реализују поменуте асоцијације и савези који делују у области спорта за све (Табела 2). 
Табела 2 Програми и кампање са циљем промовисања рекреативних активности

\begin{tabular}{|c|c|c|}
\hline & Назив програма & Опис вежбања - циљ активности \\
\hline 1968 & ЕХПО-ЗИМ & $\begin{array}{l}\text { Међународна сајамска приредба првог викенда у децембру која окупља преко 15- } \\
18.000 \text { посетилаца }\end{array}$ \\
\hline 1972 & $\begin{array}{l}\text { ДАН ЗДРАВЉА СПОРТА } \\
\text { И РЕКРЕАЦИЈЕ }\end{array}$ & $\begin{array}{l}\text { Јавни часови борења, плеса, аеробика, разговори са спортистима, глумцима, } \\
\text { политичарима, као и пригодна такмичења у оријентационом кретању, екипним } \\
\text { спортовима }\end{array}$ \\
\hline 1972 & ПРОМОТИВНИ ИЗЛЕТИ & Бициклом, аутобусом или пешице \\
\hline 1990 & $\begin{array}{l}\text { СВЕТСКИ ДАН } \\
\text { ПЕШАЧЕЊА }\end{array}$ & Организује се од почетка 90 -тих, реализује се средином октобра \\
\hline 1991 & $\begin{array}{l}\text { ФЕСТИВАЛ ЛЕТњЕ } \\
\text { РЕКРЕАЦИЈЕ }\end{array}$ & $\begin{array}{l}\text { Догађај који промовише здрав начин живота и окупља поклонике активног начина } \\
\text { живљења и односа према себи и околини }\end{array}$ \\
\hline 1993 & ДАН ИЗАЗОВА & $\begin{array}{l}\text { Утврдити који је „спортскији” град у Србији, односно у којој средини је присутнији } \\
\text { „спорт у слободно време” као једно од мерила развијености учешћа у спорту }\end{array}$ \\
\hline 1993 & ЈУ СКИ ФЕСТ & $\begin{array}{l}\text { Међународни фестивал зимских спортско рекреативних активности и такмичења на } \\
\text { снегу, стручни и едукативни програм и друштвено забавне активности }\end{array}$ \\
\hline 2000 & $\begin{array}{l}\text { ЗИМСКИ ФЕСТИВАЛ } \\
\text { ДЕЧЈЕ РЕКРЕАЦИЈЕ }\end{array}$ & $\begin{array}{l}\text { Фестивал је предвићен за ученике од } 10 \text { до } 14 \text { година, до сада је одржан на } \\
\text { Дивчибарама, Тари, Златибору и Копаонику. На основу јавне евиденције учествовања, } \\
\text { учесници добијају дипломе }\end{array}$ \\
\hline 2005 & $\begin{array}{l}\text { СВЕТСКИ ДАН БЕЗ } \\
\text { АУТОМОБИЛА }\end{array}$ & $\begin{array}{l}\text { Традиционална манифестација међусобног подстицања на мање коришћење } \\
\text { аутомобила у превозу на посао пре свега, промоција ходања и вожња бицикла за све } \\
\text { дистанце краће од 3-5 км }\end{array}$ \\
\hline 2010 & ДАН БЕЗ ЛИФТОВА & $\begin{array}{l}\text { Заједничка акција свих чланица асоцијације, друштвено одговорних компанија, } \\
\text { установа које подржавају здраве стилове живота и смањено коришћење лифтова и } \\
\text { покретних степеница, који су тог дана симболично ван употребе }\end{array}$ \\
\hline 2012 & $\begin{array}{l}\text { ЕВРОПСКА НЕДЕЉА } \\
\text { СПОРТСКОГ ИЗАЗОВА }\end{array}$ & $\begin{array}{l}\text { Европска унија финансира пригодне промотивне акције и манифестације последње } \\
\text { недеље септембра }\end{array}$ \\
\hline 2012 & FLASH MOB & $\begin{array}{l}\text { Групне кореографије и заједничко промотивно јавно вежбање које се најављује, } \\
\text { објављује и коментарише пре свега на друштвеним мрежама }\end{array}$ \\
\hline 2014 & $\begin{array}{l}\text { ЕВРОПСКЕ } \\
\text { ИНИЦИЈАТИВЕ У } \\
\text { СРБИЈИ }\end{array}$ & $\begin{array}{l}\text { Европски час физичког васпитања, Европска недеља фитнеса, Европска недеља } \\
\text { школског спорта }\end{array}$ \\
\hline
\end{tabular}

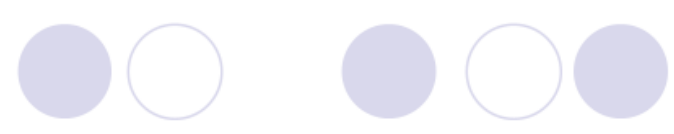

Local Community on World Challange Day in Serbia from 1993-2016
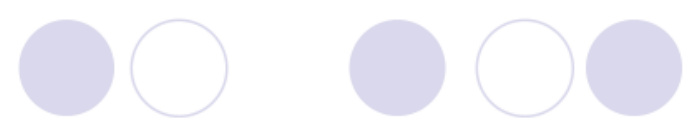

Participants on World Challange Day in Serbia from 1993-2016

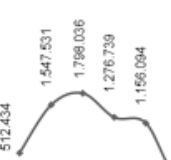

График 3 Одзив грађана Србије и учешће у Дану изазова (1993-2016) 
На графику 3 се види прираст броја учесника на Дану изазова у протекле 24 године. Иначе, овај програм је био и „стручни полигон“ за реализацију и евалуацију великог броја модела подстицања грађана на учешће у физичкој активности (дан отворених врата, лутрија, рекордер дана, мини турнири и слично). Активности наведене у табели 2 се могу сврстати у промоцију здравља вежбањем. Без претензија да се наброје све, неке ипак, међународно препознатљивог бренда, заслужују да се именују и да им се на овај начин искаже поштовање трајању, домету, значају, организацији:

- Крос издавачких кућа Политике и Борбе спада у манифестације са најдужом традицијом која се одржала до данашњих дана у нешто скромнијој и данас пре свега у такмичарској форми;

- Крос РТС у сарадњи са Министарсвом просвете, науке и технолошког развоја је најбројнији, јер се у истом тренутку реализује у свим школама Србије;

- Бели кроз је покренут још ‘73. и редовно се одржава крајем јануара, окупља спортисте који се такмиче и заљубљенике трчања;

- Фрушкогорски маратон више од четри деценије окупља поклонике оријентационог кретања и такмичења у природи;

- од 1988. Београд је ушао у породицу градова које организују маратонску трку која има и своју Трку задовољства (Fun ran) која окупља хиљаде рекреативаца;

- „Обиђи круг и буди ми друг“ је почетком ‘90-тих на Ади Циганлији покренуо Атлетски клуб Раковице, као промотивну трку која се организује у току пролећа и јесени сваких месец дана. Постоји Листа рекордера по полу и по узрасту, од 4. до 84. година старости;

- „Street basket“ као систем такмичења замењује некадашња такмичења под називом „Клинци из моје улице“ и одвија се под окриљем кошаркашке организације и невладиних организација које постају незаобилазни део начина финансирања после 2000. Евидентирамо да смо у новом формату такмичења у баскету 3 на 3 на сва три одржана такмичења освојили највећа одличја.
Поред постојећих организација у систему рекреативног спорта, а као потреба суочавања са изазовима савременог друштва, региструје се повећано интересовање и учешће здравствених институција. Тако Батутов Институт покреће националну кампању за здравље под називом „Ваше срце у вашим рукама“ током које кроз серију промотивних предавања и стручних скупова оспособљавају здравствене раднике за превентивним активностима у раду са грађанима.

Национални просветни савет је усвојио мере за побољшање здравља деце и омладине унапређивањем наставе физичког васпитања. Документ је припремила Међуресорна радна група у којој су били представници: Министарства просвете, науке и технолошког раразвоја, Министарства здравља, Министарства омладине и спорта, Савеза за школски спорт, Заједнице учитељских факултета Србије, Завода за спорт и медицину спорта РС, Друштва педагога физичке културе Србије, Завода за унапређивање образовања и васпитања, Завода за вредновање квалитета образовања и васпитања, Факултета спорта и физичког васпитања Универзитета у Београду, Сталне конференција градова и општина, Савеза учитеља Републике Србије. Међуресорна сарадња је настављена, тако да евидентирамо да су сва министарства, свако у свом домену, истрајавао на налажењу решења за дефинисане правце деловања, и то:

- Министарство просвете, науке и технолошког развоја је школска спортска такмичења уврстило укалендар активности. „Недеље школског спорта“ је ушла у Закон, а актуелно Министарство је формирало нов начин организације и реализације изабраног спорта за ученике 5. разреда.

- Министартво омладине и спорта је у Закону о спорту из 2013. школске сале прогласило за спортске објекте, чиме је створен правни основ за изградњу, реконструкцију и опремање из фондова за спорт МОС и ЈЛС. Такође, Закон из 2016. школе проглашава за спортске организације и тако ствара правни основ да могу да конкуришу за програмска средства код ЈЛС.

Савез за школски спорт од 2011. г. почиње да добија више средстава за школска спортска такмичења и нове програмске активности. Од 
2013. почиње пројекат „Спорт у школе“ у 88 општина, а поред тога Смедерево, као пример добре праксе, ангажује из својих средстава за плаћање још око 40 професора физичког васпитања за реализацију програма.

Стална конференција градова и општина са MOC организује Националну конференцију о спорту у ЈЛС, серију радионица по окрузима и уз подршку владе Швајцарске финансира израду три приручника за област спорта и финансирање спорта у ЈЛС.

Акциони план за реализацију Стратегије развоја спорта за период 2014-2018, поред система школских спортских такмичења, препознаје и дефинише ванчасовне активности као облике наставе које може да суфинансира ресорно министарство или ЈЛС. У опису овог програма се истичу: спортска секција „по детету“, курсни облици наставе, летовања, зимовања, спортско рекреативни кампови, нови модели СПРЕТ-а који се заснивају на вредновању учествовања, викенд и распуст у школском дворишту и сл. Важно је истаћи да је овај Акциони план преузело и преко 130 ЈЛС, које су направиле своје програме развоја спорта.

\section{ВЕРТИКАЛНА ОРГАНИЗАЦИЈА И ПРОГРАМСКО ФИНАНСИРАҢЕ РЕКРЕАТИВНОГ СПОРТА}

Закон о спорту прави разлику између савеза за одређену грану спорта (грански спортски савези), спортских савеза за спортску рекреацију, односно савеза за спорт у институцијама (школски и универзитетски спорт, спорт у војсци, спорт у полицији и др.). Како спортска рекреација и спорт у институцијама не припадају спорту у ужем смилу, то је било потребно да се Стратегијом спорта предвиде модели организовања којима би се повезале оргнизације унутар спортске рекреације, односно организације спорта у институцијама. Повезивање је предуслов омасовљења,организовања такмичења и развоја спортске активности којој припадају.

Закон кроз вертикалну организацију спорта усмерава уставну категорију као право свих грађана да се баве спортом. Њиме се посебно наглашава обавеза јединица локалне самоуправе на стицање и неговање навика редовне физичке активности (Закона о спорту)
Јединице локалне самоуправе имају посебно значајно место у примени стратегије. Законом о спорту је дефинисано да је обавеза сваке јединице локалне самоуправе да утврди програм развоја спорта на својој територији који ће бити у сагласности са овом стратегијом, а да ће се у расподели средстава водити рачуна о критеријума прописаним на републичком нивоу и да ће цео процес бити јаван и транспарантан. Циљ Националне стратегије је сужавање простора за коришћење тзв. дискреционих права локалних руководиоца која су често била и извор корупције у спорту.

Закон о спорту је установио програмско финансирање задовољавања потреба и интереса грађана у јединици локалне самоуправе Јединица локалне самоуправе искључиво финансира програм којим се у текућој години задовољавају законом утврђени кртеријуми, потребе и интереси грађана заједнице. Према Закону о спорту, јединица локалне самоуправе преко својих органа уређује ближе услове, критеријуме и начин и поступак доделе средстава из буџета јединице локалне самоуправе, односно одобрење програма за задовољавање потреба грађана у области спорта на територији јединице локалне самоуправе и начин јавног објављивања података о предложеним програмима за финансирање, одобреним програмима и реализацији одобрених програма. Програмско финансирање и критеријуми за одбир програма подразумева обавезно доношење правилника којим би се уредили наведена питања у вези са финансирањем из буџета.

Стабилан проценат финансирања програма спорта за све на нивоу централне државе се креће од 3-5\% од буџета спорта, односно 15$20 \%$ на нивоу ЈЛС. Ово је модел који може да гарантује остварење обухвата грађана редовном и квалитетном физичком активности.

Значајан део Националног буџета за спорт распоређује се на национална признања заслужним спортистима и тренерима. Преостали део буџета, његових 70\% се опредељује за рад националних спортских организација са врхунским резултатима. Школски спорт повлачи око $15 \%$ средстава, а спортска рекреација, спорт за све и рекреативни спорт, да би могли да реализују планирано повећање обухвата грађана спортом потражује и добијају око 5\% средстава. 


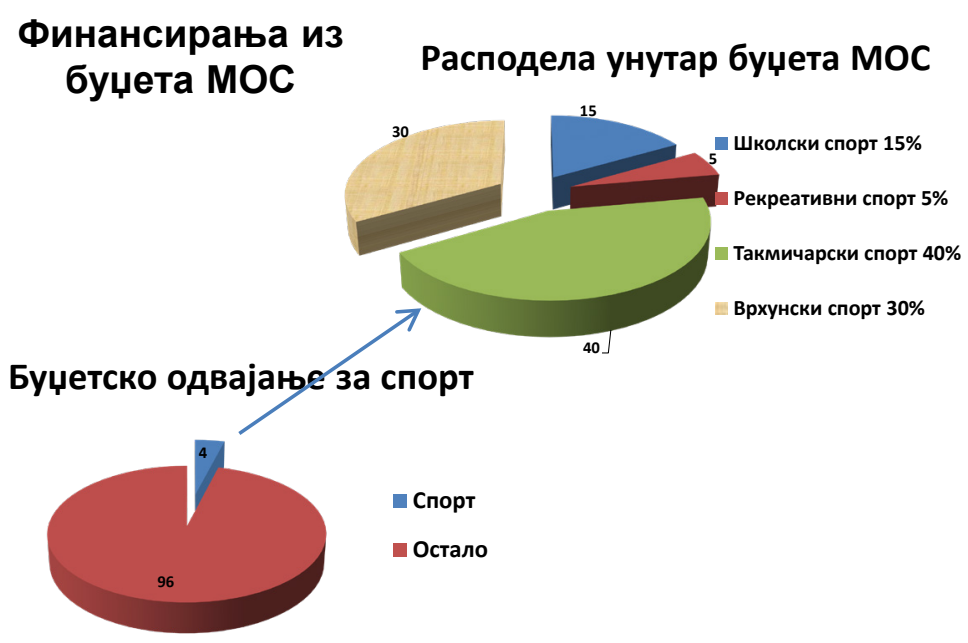

Слика 2 Расподела буџета Министарства омладине и спорта

Највећи обим активности, који су дефинисани како Законом о спорту, тако и приоритетима националне Стратегије развоја спорта, реализује се на нивоу ЈЛЗ. Први корак у реализацији стратешких циљева и акционог плана био је да се за делатност целине спортског покрета одвоји препоручених $4 \%$ средстава укупног буџета ЈЛС. У следећем кораку, била је неопходна прерасподела буџета за спорт према приоритетним областима дефинисаних Националном стратегијом. Тако се школски спорт, који је Стратегијом постављен много шире, почев од опредељења да се реализује спортска секција по детету, преко курсних облика наставе, недеље школског спорта, промотивних модела такмичења на бази учествовања, ваучера за вежбање средњошколаца и студената, викенда у школском дворишту и сл. опредељује 20\% локалног буџета спорта. Спортска рекреација, спорт за све, рекреативни спорт за повећање обухвата грађана спортом ради здравља пре свега потражује минимално 15\% буџета. Такимичарски спорт је и даље доминантан корисник са око $60 \%$ средстава. Поједине ЈЛЗ у складу са достигнутим спортским резултатима подржавају и своје врхунске спортисте кроз финансирање трошкова закупа простора за тренинг, рад млађих селекција и слично.

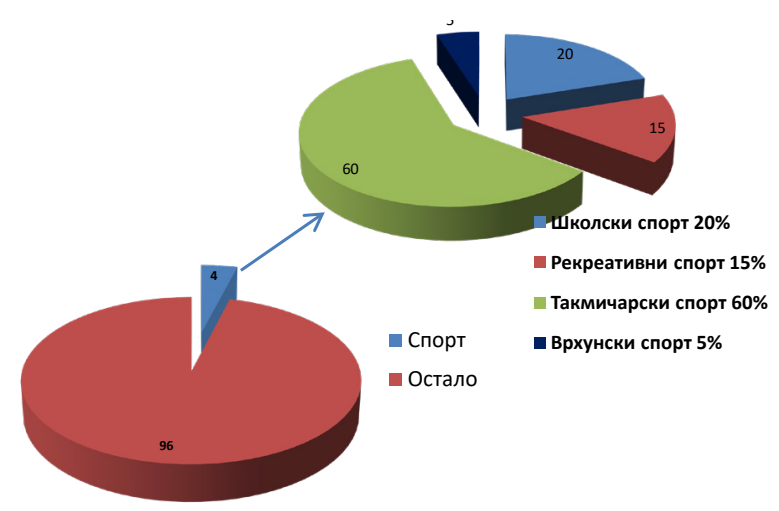

Слика 3 Кораци и структура у расподели буџета за спорт на нивоу ЈЛЗ 
Спорт за све је комплексна област која обухвата разнородне корисничке групе и њихова интересовања. Досадашња пракса расподеле средстава изнедрила је неколико модалитета програма који се могу груписати као: (а) програми редовног вежбање (током године), (б) повремене - сезонске активности; и (в) акције и манифестације које су промотивног карактера. Поред овог, важни су критеријуми за вредновање програма који треба да излуче подстицање деце и младих да прихвате редовну физичку активност, односно програми који су кадри да излуче мере за учешће у физичком вежбању угрожених категорија грађана где спадају жене, незапослене особе, старији грађани, инвалидна лица и др.

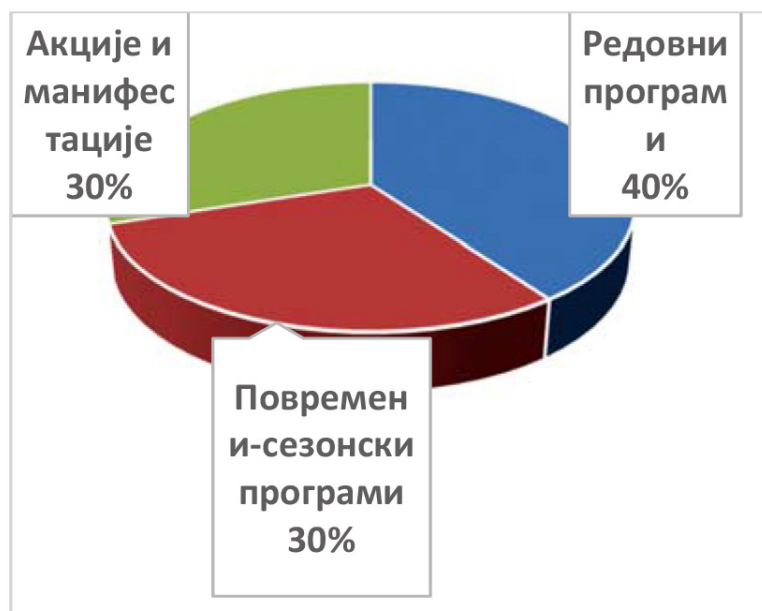

Слика 4 Расподела средстава унутар области рекреативног спорта, спорта за све, масовног спорта

Закон о спорту прави битну разлику између редовних - годишњих и посебних програма. Посебни програми се не разлику по својој суштини - физичка активност грађана, већ према правним лицима који могу да их поднесу и према динамици подношења. Ради се о програмима који се финансирају средствима која се прерасподељују из простора добити лутрије, кладионица и игара на срећу.

\section{ЗАКЉУЧАК}

Спорт у ширем смислу, као редовна физичка активност доприноси реализацији великог броја социјалних циљева и вредности. Родна равноправност, међуверска и међурасна разумевања и толеранција, равноправност, једнакост... те се као својеврсан феномен планира и реализује као средство од значаја за побољшање квалитета живота поједница, породице, локалне самоуправе и друштва.

Масовни спорт, рекреација, спорт за све, спортска рекреација се после неколико деценија занемаривања, од 2006. године налази на агенди друштва и поново постаје један од приоритета реализације циљева спортског покрета у Републици Србији. До овог места и значаја се стигло промишљеном акцијом спортског покрета у периоду израде Устава Републике Србије (2006). Ови облици физичке активности су се нашли у Закону о спорту, делови су стратешких докумената развоја друштва Србије.

Декаду за нама (2006-2016) у простору афирмације рекреативног спорта карактерише међуресорно деловање Министарстава просвете, науке и технолошког раразвоја; здравља; омладине и спорта, заједно са Савезом за школски спорт, Друштвом педагога физичке културе Србије, Заводом за унапређивање образовања и васпитања, Заводом за вредновање квалитета образовања и васпитања, Факултета спорта и физичког васпитања Универзитета у Београду, Сталне конференција градова и општина али и грађанских иницијатива којима, сви побројани актери, теже креирању амбијента према редовној физичкој активности, вежбању и здравим стиловима живота.

\section{Напомена:}

Рад представља резултат рада на пројекту „Унапређење квалитета и доступности образовања процесима модернизације Србије“, број III 47008, чију реализацију финансира Министарство просвете, науке и технолошког развоја Репубике Србије (2011-2018). 


\section{ЛИТЕРАТУРА}

1. Хрчка, J. (1975). Значај ширења знања о улоази спортско рекреативних активности. Физичка култура, 1: 35-41.

2. Вуори, И. (1996). Друштвени значај спорта: Зашто и како спорт и физичка активност доприносе Јавном здрављу. Физичка култура 4: 341-346.

3. Матић, М. (1991). „Рекреација: у потрази за системском дефиницијом појма. Физичка култура, 4: 290- 297.

4. Матић, М.(1992). „Рекреација-алиас немиp(ење)“. Годишњак 4:144-152.

5. Смодлака, В. (1996). Физичка активност и здравље - Извештај „Surgeon General“. Фuзичка култура, 4: 363-365.

6. Института за јавно здравље Србије „Др Милан Јовановић Батут" (2014). Резултати истраживања здравља становништва Србије. Београд

7. Покрајац Б. (1992). Психолошки смисао рекреације. Годишъак, 4:188-193.

8. Ђурђевић, Н., Митић, Д., Атанасов, Д., Вујовић, Б. (2014). Спорт у јединицама локалне самоуправе - Приручник за финансирање програма развоја спорта. Стална конференција градова и општина Савез градова и општина Србије, Београд.

\section{Документа:}

1. European Commission/EACEA/Eurydice, 2013. Physical Education and Sport at School in Europe

2. European Opinion Research Group 2003.

3. Закон о спорту, Службени гласник РС, бр. $10 / 2016$

4. Образложење Предлога Закона о спорту у РС 2013.

5. Смодлака Војин - писмо од 11. IX 1995.

6. Стартегија развоја спорта у Републици Србији 2014.д о 2018.г., поглавље: „Стратегија развоја школског спорта 2014-2018“., Министарство омладине и спорта, Београд.

7. Стратегија развоја школског спорта у АП Војводина 2013-2017. Покрајински секретаријат за спорт, Нови Сад.

8. Стратегија и акциони план развоја школског спорта у Аутономнј покрајини Војводини за период 2013-2017.године. Покрајински секретаријат за спорт. Нови Сад.

9. Уредба о Националном програму превенције, лечења и контроле кардиоваскуларних болести у Републици Србији до 2020. године

10. http://serbianfood.info/publications/Uredba_o_ nacionalnom_programu_prevencije_2020/ Uredba_o_nacionalnom_programu_prevencije_2020.pdf 